\title{
Accuracy of methane emissions predicted from milk mid-infrared spectra and measured by laser methane detectors in Brown Swiss dairy cows
}

\author{
T. M. Denninger, ${ }^{1}$ A. Schwarm, ${ }^{1,2}$ F. Dohme-Meier, ${ }^{3}$ A. Münger, ${ }^{3}$ B. Bapst, ${ }^{4}$ S. Wegmann, ${ }^{4}$ F. Grandl, ${ }^{4}$ \\ A. Vanlierde,${ }^{5}$ D. Sorg,${ }^{6,7}$ S. Ortmann, ${ }^{8}$ M. Clauss, ${ }^{9}$ and M. Kreuzer ${ }^{1 *}$ \\ ${ }^{1}$ ETH Zurich, Institute of Agricultural Sciences, Universitaetstrasse 2, 8092 Zurich, Switzerland \\ ${ }^{2}$ Department of Animal and Aquacultural Sciences, Norwegian University of Life Sciences, PO Box 5003, 1432 Ås, Norway \\ ${ }^{3}$ Agroscope, Ruminant Research Unit, Route de la Tioleyre 4,1725 Posieux, Switzerland \\ ${ }^{4}$ Qualitas AG, Chamerstrasse 56, 6300 Zug, Switzerland \\ ${ }^{5}$ Valorisation of Agricultural Products Department, Walloon Agricultural Research Centre, Chaussée de Namur, 24, B-5030 Gembloux, Belgium \\ ${ }^{6}$ Institute of Agricultural and Nutritional Sciences - Animal Breeding, Martin Luther University Halle-Wittenberg, Theodor-Lieser-Str. 11, \\ 06120 Halle, Germany \\ ${ }^{7}$ German Environment Agency (Umweltbundesamt), Wörlitzer Platz 1, 06844 Dessau-Roßlau, Germany \\ ${ }^{8}$ Leibniz Institute for Zoo and Wildlife Research (IZW) Berlin, Alfred-Kowalke-Str. 17, 10315 Berlin, Germany \\ ${ }^{9}$ Clinic for Zoo Animals, Exotic Pets and Wildlife, Vetsuisse Faculty, University of Zurich, Winterthurerstrasse 260, 8057 Zurich, Switzerland
}

\section{ABSTRACT}

Since heritability of $\mathrm{CH}_{4}$ emissions in ruminants was demonstrated, various attempts to generate large individual animal $\mathrm{CH}_{4}$ data sets have been initiated. Predicting individual $\mathrm{CH}_{4}$ emissions based on equations using milk mid-infrared (MIR) spectra is currently considered promising as a low-cost proxy. However, the $\mathrm{CH}_{4}$ emission predicted by MIR in individuals still has to be confirmed by measurements. In addition, it remains unclear how low $\mathrm{CH}_{4}$ emitting cows differ in intake, digestion, and efficiency from high $\mathrm{CH}_{4}$ emitters. In the current study, putatively low and putatively high $\mathrm{CH}_{4}$ emitting Brown Swiss cows were selected from the entire Swiss herdbook population (176,611 cows), using an MIR-based prediction equation. Eventually, 15 low and 15 high $\mathrm{CH}_{4}$ emitters from 29 different farms were chosen for a respiration chamber (RC) experiment in which all cows were fed the same forage-based diet. Several traits related to intake, digestion, and efficiency were quantified over $8 \mathrm{~d}$, and $\mathrm{CH}_{4}$ emission was measured in 4 open circuit RC. Daily $\mathrm{CH}_{4}$ emissions were also estimated using data from 2 laser $\mathrm{CH}_{4}$ detectors (LMD). The MIR-predicted $\mathrm{CH}_{4}$ production $(\mathrm{g} / \mathrm{d})$ was quite constant in low and high emission categories, in individuals across sites (home farm, experimental station), and within equations (first available and refined versions). The variation of the MIR-predicted values was substantially lower using the refined equation. However, the predicted low and high emitting cows (n $=28$ ) did not differ on average in daily $\mathrm{CH}_{4}$ emissions

Received June 13, 2019.

Accepted October 22, 2019.

*Corresponding author: michael.kreuzer@usys.ethz.ch measured either with RC or estimated using LMD, and no correlation was found between $\mathrm{CH}_{4}$ predictions (MIR) and $\mathrm{CH}_{4}$ emissions measured in RC. When individuals were recategorized based on $\mathrm{CH}_{4}$ yield measured in RC, differences between categories of 10 low and 10 high $\mathrm{CH}_{4}$ emitters were about 20\%. Low $\mathrm{CH}_{4}$ emitting cows had a higher feed intake, milk yield, and residual feed intake, but they differed only weakly in eating pattern and digesta mean retention times. Low $\mathrm{CH}_{4}$ emitters were characterized by lower acetate and higher propionate proportions of total ruminal volatile fatty acids. We concluded that the current MIR-based $\mathrm{CH}_{4}$ predictions are not accurate enough to be implemented in breeding programs for cows fed forage-based diets. In addition, low $\mathrm{CH}_{4}$ emitting cows have to be characterized in more detail using mechanistic studies to clarify in more detail the properties that explain the functional differences found in comparison with other cows.

Key words: digestion, feed efficiency, methane prediction, proxy

\section{INTRODUCTION}

Methane is a greenhouse gas with a global warming potential that is more than 20 times greater than that of carbon dioxide. The global livestock sector accounts for $18 \%$ of anthropogenic greenhouse gas emissions, and $\mathrm{CH}_{4}$ from ruminants is the main source (Steinfeld et al., 2006). The research effort toward $\mathrm{CH}_{4}$ mitigation is ongoing. Apart from the available set of efficient dietary interventions (Hristov et al., 2013), targeted animal breeding has emerged as a promising and, if successful, sustainable mitigation strategy (de Haas et al., 2017). Breeding progress is possible if a trait is sufficiently 
heritable and if phenotypic data are available from populations relevant for genetic selection purposes. The first is given because $\mathrm{CH}_{4}$ emissions were found to be a heritable trait (e.g., Lassen and Løvendahl, 2016; Jonker et al., 2017) and the phenotype seems to be persistent throughout lactation (Garnsworthy et al., 2012b). However, it should be noted that Münger and Kreuzer (2008) did not find such a persistence. With respect to the need for individual animal data sets, the well-established techniques for measuring $\mathrm{CH}_{4}$ from cows, respiration chambers (RC) and sulfur hexafluoride $\left(\mathrm{SF}_{6}\right)$, are not fast and cheap enough. The laser $\mathrm{CH}_{4}$ detector (LMD) has been used to measure $\mathrm{CH}_{4}$ concentrations in cow's breath over a short time period to estimate daily $\mathrm{CH}_{4}$ emissions, and it might allow a quick ranking of animals by $\mathrm{CH}_{4}$ emission on farm (Chagunda et al., 2013; Sorg et al., 2018). Similar to RC, the LMD technique can be applied for all ruminant species and production purposes. One of the most promising proxies for $\mathrm{CH}_{4}$ emission is based on the mid-infrared (MIR) spectra of the milk (Vanlierde et al., 2016, 2018). This proxy is currently limited to lactating cattle for which the milk recording scheme is in place and calibrated. The underlying equation has been, and is, continuously refined by extending calibration and reference $\mathrm{CH}_{4}$ measurement data sets. Mid-infrared spectra are available from national milk recording schemes. Therefore, this proxy only requires electronic storage efforts.

The next logical step in validating the MIR approach relies on a backward approach, namely screening entire cow populations for low $\mathrm{CH}_{4}$ emitters and measuring the accuracy of the corresponding $\mathrm{CH}_{4}$ predictions. This process was recently done with a single herd (Denninger et al., 2019), but it has not yet been applied to cow population data. If this validation is successful, the proxy could be used in breeding programs. In addition, the data could be useful for national inventory purposes, as well as potential payment or taxing regimens based on greenhouse gas emissions from dairy cows. As cows are exposed to a variety of farm-specific influences on $\mathrm{CH}_{4}$ emissions, including diet type, intake, feeding frequency, and physiological state of the animal (Garnsworthy et al., 2012b; Hristov et al., 2013; Goopy et al., 2014), this step also has to clarify whether the differences in $\mathrm{CH}_{4}$ prediction between cows are of sufficient magnitude to be detected when cows from different locations are kept in the same housing and feeding environment. In the development of the equation, data from various breeds, sites, and feeding regimens were integrated, but they nonetheless originated from experimental herds. Finally, it is still unclear how low $\mathrm{CH}_{4}$ emitters differ from high $\mathrm{CH}_{4}$ emitters in terms of specific traits and the extent to which they vary. Low
$\mathrm{CH}_{4}$ emitters might exhibit a greater feed efficiency (ECM/DMI), as shown by a lower residual feed intake (RFI; Hegarty et al., 2007; Alemu et al., 2017). Previous research indicated that low $\mathrm{CH}_{4}$ emitting sheep could have a proportionately smaller rumen (Goopy et al., 2014), and low $\mathrm{CH}_{4}$ emitting cattle have been reported to have a low cell wall digestibility (CabezasGarcia et al., 2017). The latter differences, however, would be expected to result in a lower feed efficiency.

The objective of the current study was to test the feasibility of using $\mathrm{CH}_{4}$ predictions from milk MIR spectra to identify truly low $\mathrm{CH}_{4}$ emitting dairy cows on the basis of milk recording data. The hypotheses tested were the following: (1) MIR-based predictions of $\mathrm{CH}_{4}$ production of individual cows on farm are recoverable on a uniform diet at the experimental station; (2) the MIR predictions closely correlate with individual $\mathrm{CH}_{4}$ emission measurements made with RC and LMD; and (3) compared with high $\mathrm{CH}_{4}$ emitters, low $\mathrm{CH}_{4}$ emitting cows are superior in feed and digestive efficiency.

\section{MATERIALS AND METHODS}

\section{Screening of the Cow Population and Selection of Low and High $\mathrm{CH}_{4}$ Emitters}

A milk MIR prediction equation (Vanlierde et al., 2016; modified as described below) was used to predict the daily enteric production of $\mathrm{CH}_{4}\left(\mathbf{P}_{\mathrm{m}} ; \mathrm{g} / \mathrm{d}\right)$ of individual cows from MIR spectra stored from each test day, between January 2016 and July 2017, for 175,980 Brown Swiss and Braunvieh dairy cows in Switzerland. Only cow data that met the following criteria were included when identifying low and high $\mathrm{CH}_{4}$ emitting cows: milk yield 5 to $60 \mathrm{~kg} / \mathrm{d}$, 4 to 306 DIM, 150 to 950 $\mathrm{g} / \mathrm{d} \mathrm{P}_{\mathrm{m} \text { MIR }}$, and availability of data from at least 5 milk recordings per cow. Records from summer alpine grazing periods and from farms located in the highest mountain regions were excluded. A linear mixed model considering log-transformed milk yield, log-transformed DIM, parity, and season within year as fixed effects, as well as cow and farm as random effects, was applied to model $\mathrm{P}_{\mathrm{m}}$ by using the nlme R package (Pinheiro et al., 2017). The conditional modes (difference between the average predicted response at population level for a given set of fixed-effect values and the response predicted for a particular individual) for the cow effect were used to select the extreme values ( $15 \%$ of cows in both directions) for which the predicted $\mathrm{P}_{\mathrm{m}}$ was either greater or lower than expected from the linear mixed model. All cows were used for the first selection step, but later selection was restricted to cows in second parity to exclude a further potential factor of influence. This screening procedure

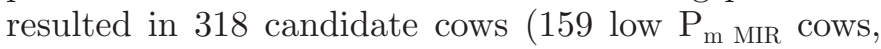


159 high $\mathrm{P}_{\mathrm{m} \text { MIR }}$ cows). From among these cows, 30 (15 low, 15 high $\mathrm{P}_{\mathrm{m} \text { MIR }}$ cows), preferably in late lactation, were randomly selected for the experiment, followed by getting the approval of the cow owner. The 30 cows originated from 29 different farms.

Although this categorization of the cows did not substantially change when MIR spectra obtained during the experiment were analyzed and different prediction equations were used, cows were later recategorized because cow allocation to the categories was largely different when the RC data were used (measurements described below). Therefore, new groups were formed based on the cows' $\mathrm{CH}_{4}$ yield $\left(\mathbf{Y}_{\mathrm{m}}\right.$; here, $\mathrm{g} / \mathrm{kg}$ of DMI) as measured with RC. This adjusted trait was chosen to exclude the advantage small cows with low feed intake would have when DMI is not considered. To be able to clearly distinguish between categories and in response to the missing preselection of cows for $\mathrm{Y}_{\mathrm{m} \text { DMI }}$ in $\mathrm{RC}$, only the $2 \times 10$ cows with either the lowest or the highest $Y_{m \text { DMI }}$, respectively, were used for the detailed comparison of the characteristics of low and high $\mathrm{CH}_{4}$ emitters.

\section{Experimental Protocol}

The experiment was conducted at the research station AgroVet-Strickhof (Eschikon, Lindau, Switzerland) from November 2017 to April 2018. The experimental protocol was approved (ZH050/17) by the Committee on Animal Experimentation of the Cantonal Veterinary Office Zurich. Owing to 4 RC being available, cows were transported in groups of 4 (2 predicted low $\mathrm{P}_{\mathrm{m}}$ and 2 high $\mathrm{P}_{\mathrm{m}}$; last time, 2 cows only) from the farms to the station and back after the experiment. This process resulted in 8 blocks of cows. During a 10-d period of adaptation to diet and management, the cows were kept in a tie-stall barn and milked in a swing-over milking system. During this time, the cows had access to an outside area for $2 \mathrm{~h}$ every second day. In the following 8-d sampling period, cows were tethered all the time, which allowed complete collection of feces and urine. On sampling d 9, the collection devices were removed and rumen fluid was sampled. In the last $24 \mathrm{~h}$ cows were housed in a RC. All cows received the same diet (Table 1), regardless of the diet they had received at their home farm. The mixed ration was composed of $55 \%$ corn silage, $38 \%$ grass silage, $2 \%$ hay, and $5 \%$ dairy concentrate (UFA-250, UFA, Sursee, Switzerland) and was offered ad libitum. In separate troughs, cows daily received, per kilogram of milk, $250 \mathrm{~g}$ of an energy-rich concentrate (UFA-243, UFA) and $125 \mathrm{~g}$ of dried grass pellets. During morning feeding, $50 \mathrm{~g} / \mathrm{d} \mathrm{NaCl}$ and 100 $\mathrm{g} / \mathrm{d}$ of a vitamin-mineral supplement were provided. The latter contained (per kg) $160 \mathrm{~g}$ of Ca, $80 \mathrm{~g}$ of P, 100 $\mathrm{g}$ of $\mathrm{Mg}, 32 \mathrm{~g}$ of Na, $10 \mathrm{~g}$ of S, $8.0 \mathrm{mg}$ of $\mathrm{Zn}, 4.0 \mathrm{mg}$ of $\mathrm{Mn}, 1.0 \mathrm{mg}$ of $\mathrm{Cu}, 30 \mathrm{mg}$ of Se, $100 \mathrm{mg}$ of I, $30 \mathrm{mg}$ of Co, 1,200,000 IU of vitamin A, 200,000 IU of vitamin $\mathrm{D}_{3}, 3,000 \mathrm{mg}$ of vitamin $\mathrm{E}$, and $150 \mathrm{~g}$ of biotin. The animals were milked at 0550 and $1645 \mathrm{~h}$ and fed at the same time. Leftovers of the mixed ration were removed before each feeding time and weighed. Energy concentrate and grass pellets were always eaten completely.

\section{Prediction of $\mathrm{CH}_{4}$ Emissions from Milk Sampling Combined with MIR Spectra Analysis}

Analysis of MIR spectra was performed either on a stored data set (population) or on milk sampled from

Table 1. Composition (\% of DM; DM: \% of wet weight) of the individual experimental feeds and amounts offered and refused (arithmetic means $\pm \mathrm{SD})$

Diet component

\begin{tabular}{|c|c|c|c|c|c|c|}
\hline \multirow[b]{2}{*}{ Item } & \multicolumn{4}{|c|}{ Mixed ration } & \multirow{2}{*}{$\begin{array}{c}\text { Energy } \\
\text { concentrate }^{2}\end{array}$} & \multirow[b]{2}{*}{ Grass pellets ${ }^{2}$} \\
\hline & $\mathrm{Hay}^{1}$ & Grass silage $^{1}$ & Corn silage $^{1}$ & Protein concentrate ${ }^{2}$ & & \\
\hline \multicolumn{7}{|c|}{$\overline{\text { Composition }}$} \\
\hline DM & $88.6 \pm 1.5$ & $35.2 \pm 4.0$ & $37.0 \pm 2.8$ & $93.1 \pm 0.0$ & $88.8 \pm 0.0$ & $90.3 \pm 0.4$ \\
\hline $\mathrm{OM}$ & $91.0 \pm 1.1$ & $88.0 \pm 1.9$ & $96.8 \pm 0.4$ & $91.0 \pm 0.0$ & $93.7 \pm 0.0$ & $87.4 \pm 0.4$ \\
\hline $\mathrm{CP}$ & $9.8 \pm 2.3$ & $13.9 \pm 1.6$ & $6.7 \pm 0.9$ & $31.7 \pm 0.3$ & $22.8 \pm 0.3$ & $17.3 \pm 0.6$ \\
\hline NDF & $49.3 \pm 4.6$ & $39.9 \pm 3.6$ & $45.2 \pm 4.0$ & $14.5 \pm 1.5$ & $27.1 \pm 1.2$ & $40.2 \pm 2.5$ \\
\hline $\mathrm{ADF}$ & $35.8 \pm 3.8$ & $31.9 \pm 3.1$ & $27.8 \pm 3.4$ & $11.0 \pm 0.1$ & $10.8 \pm 0.1$ & $26.3 \pm 3.0$ \\
\hline ADL & $4.80 \pm 0.91$ & $4.55 \pm 1.52$ & $3.49 \pm 0.95$ & $5.78 \pm 0.04$ & $3.65 \pm 0.03$ & $4.50 \pm 0.35$ \\
\hline $\mathrm{EE}^{3}$ & $1.68 \pm 0.28$ & $2.88 \pm 0.42$ & $3.41 \pm 0.25$ & $2.03 \pm 0.01$ & $7.41 \pm 0.16$ & $3.15 \pm 0.46$ \\
\hline \multicolumn{7}{|c|}{ DM amounts $(\mathrm{kg} / \mathrm{d})$} \\
\hline Offered & $0.64 \pm 0.19$ & $4.94 \pm 0.47$ & $7.34 \pm 0.52$ & $1.75 \pm 0.25$ & $1.27 \pm 0.43$ & $0.63 \pm 0.22$ \\
\hline Refused & $0.13 \pm 0.05$ & $0.86 \pm 0.28$ & $0.49 \pm 0.15$ & $0.11 \pm 0.35$ & 0 & 0 \\
\hline
\end{tabular}

${ }^{1} \mathrm{n}=19$.

${ }^{2} \mathrm{n}=3$.

${ }^{3} \mathrm{EE}=$ ether extract. 
Table 2. Overview and definitions of mid-infrared (MIR) assessments, categorization of cows into low and high $\mathrm{CH}_{4}$ emitters, and MIR-based equations used

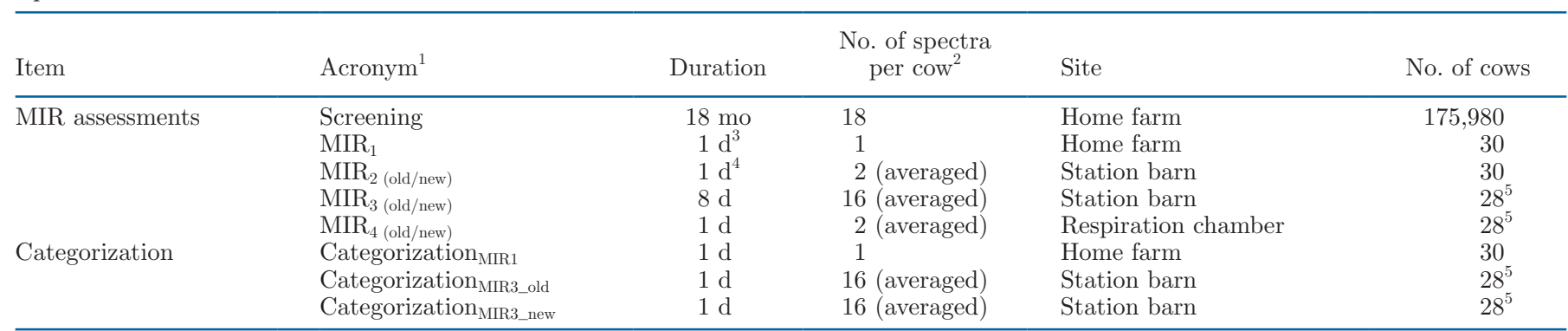

${ }^{1}$ Old equation $=$ equation available at the time of the experiment; new equation $=$ further developed equation now available.

${ }^{2}$ If morning and evening milks were collected or collection was performed across several days, the spectra were averaged proportionately to milk yield to 1 spectrum following Vanlierde et al. (2015).

${ }^{3}$ From last routine performance recording before the experiment (July 2017).

${ }^{4}$ At arrival at station.

${ }^{5}$ Two high $\mathrm{P}_{\mathrm{m} \text { MIR }}$ cows had severe diarrhea and were excluded.

the 30 cows either on their home farm or at the research station. The spectra were obtained using Fourier transform infrared spectrophotometry (MilkoScan FT6000 Foss Electric, Hillerød, Denmark). They were standardized according to the Grelet et al. (2017) procedure to avoid instrumental interference and ensure comparability of the spectra regardless the spectrometer used. From these spectra, $\mathrm{P}_{\mathrm{m} \text { MIR }}$ was first predicted using the lactation-stage-dependent prediction equation developed by partial least-square regression from Vanlierde et al. (2016). The published prediction equation was slightly modified for this purpose by including milk spectra and corresponding $\mathrm{CH}_{4}$ measurements from 77 Swiss cows in the calibration data set for deriving the prediction equation. This process yielded $225 \mathrm{RC}$-based $\mathrm{CH}_{4}$ measurements in addition to the $532 \mathrm{SF}_{6}$-based $\mathrm{CH}_{4}$ measurements in the original calibration data set of Vanlierde et al. (2016). The standard error of calibration (SEC) of this equation, later called the "old equation," was $70 \mathrm{~g} / \mathrm{d}$, the calibration coefficient determination $\left(\mathbf{R}^{2} \mathbf{c}\right)$ was 0.66 , the standard error of cross-validation (SECV) was $73 \mathrm{~g} / \mathrm{d}$, and the cross-validation coefficient of determination $\left(\mathbf{R}^{2} \mathbf{c v}\right)$ was 0.62. After the experiment had been completed, the prediction equation was further refined. The "new equation" was developed and calibrated in 2019 using 1,089 RC- and $\mathrm{SF}_{6}$-based $\mathrm{CH}_{4}$ measurements $(7 \%$ from Brown Swiss cows) originating from 299 cows (13\% Brown Swiss cows). This new equation had an SEC of $58 \mathrm{~g} / \mathrm{d}$, an $\mathrm{R}^{2} \mathrm{c}$ of 0.68 , an SECV of $61 \mathrm{~g} / \mathrm{d}$, and an $\mathrm{R}^{2} \mathrm{cv}$ of 0.64. Following Vanlierde et al. (2016) and considering the spectral data set used to build the equation as the reference, we removed Swiss spectra obtained during this study with a standardized Mahalanobis distance (global H distance; GH) of $>3$ from the data set. Based on the GH procedure, only $0.72 \%$ of the current data set needed to be removed. With both equations, predicted $\mathrm{P}_{\mathrm{m} \text { MIR }}$ values of $<150 \mathrm{~g} / \mathrm{d}$ or $>950 \mathrm{~g} / \mathrm{d}$ were excluded from further analyses and considered as outliers as described by Vanlierde et al. (2016, 2018). The new prediction equation was applied to evaluate whether cow allocation was robust when the $\mathrm{P}_{\mathrm{m}}$ prediction equation changes and to determine whether correlations with measured $\mathrm{CH}_{4}$ data were improved. In detail, $\mathrm{P}_{\mathrm{m} \text { MIR }}$ was predicted from MIR spectra 5 times with both the old and new equations (only the former was available at the time of the screening). Description and denominations are given in Table 2.

\section{Measurement of Daily $\mathrm{CH}_{4}$ Emissions Using RC}

Four new RC (No Pollution, Industrial Systems Ltd., Edinburgh, UK) were used to measure $\mathrm{CH}_{4}$ emissions from the individual cows at AgroVet-Strickhof. The chambers were $4.75 \mathrm{~m}$ wide, $3.25 \mathrm{~m}$ deep, and $2.5 \mathrm{~m}$ tall $\left(38.6 \mathrm{~m}^{3}\right)$. Each chamber was fitted with 1 large back door for animal entrance, 1 smaller front door, safety opening devices, and rubber seals around the whole perimeter of each opening. The animals were tied in metabolism stalls $(255 \times 150 \mathrm{~cm})$ equipped with water troughs and feed bins mounted on an electronic balance. The doors were opened for a very short time twice daily at the same time for milking and feeding. These openings were accounted for by interpolating about $2 \times$ $20 \mathrm{~min} / \mathrm{d}$ with values from adjacent times in which gas concentration had returned to the equilibrium. Fresh air was supplied via a common duct through 2 shutters (SPI-F-160, Systemair AB, Buchs ZH, Switzerland and LM 230, Belimo Automation AG, Hinwil, Switzerland) to prevent backflow. The air was exchanged about 12 
times/h. Temperature was maintained at $16^{\circ} \mathrm{C}$, with relative humidity at $60 \%$. Spent air was removed by an extraction fan (K06-MS Blower, FPZ Blower Technology, Concorezzo, Italy), coupled with a frequency controller (3.3-kW VLT HWAC Drive, Danfoss GmbH, Offenbach, Germany) maintaining an airflow between 19.0 and $23.0 \mathrm{~L} / \mathrm{s}$. The chambers were kept under a slight negative pressure. The $\mathrm{CH}_{4}$ concentration was determined with an MGA 3500 (ADC Gas Analysis Ltd., Hertfordshire, UK) using nondispersive infrared absorption. This measurement was done every $10 \mathrm{~min}$ in the outgoing chamber air and in the fresh air collected on the roof of the building where the air pipe for the $\mathrm{RC}$ was installed. Calibration was performed directly before and after each experimental run. To start, a pure $\mathrm{N}_{2}$ gas (99.999\%) was applied. Then, the first standard gas mixture containing $0.1 \% \mathrm{H}_{2}$ and $99.9 \% \mathrm{~N}_{2}$ was delivered for 3 min until $\mathrm{H}_{2}$ level stabilized, which was followed by pure $\mathrm{N}_{2}$ gas for 3 min. Next, a second standard gas mixture $\left(0.08 \% \mathrm{CH}_{4}, 20.9 \% \mathrm{O}_{2}, 0.4 \% \mathrm{CO}_{2}\right.$, and $78.62 \% \mathrm{~N}_{2}$ ) was delivered to let the instrument return to the expected concentrations. A recovery test (total calibration) for $\mathrm{CH}_{4}$ was performed 3 times per chamber during the experiment. While the regular data collection was performed, $\mathrm{CH}_{4}(99.9 \%)$ was injected at $0.35 \mathrm{~L} / \mathrm{min}$ via a tube through the outside wall for $4 \mathrm{~h}$. The measured concentration reached a plateau after 1 to $2 \mathrm{~h}$. The flow rate was controlled by a Sierra mass flow controller (MC-5SLPM-RD, Alicat Scientific, Tucson, AZ). The calibration of the chambers and the gas analyzers provided a calibration factor for $\mathrm{CH}_{4}$. The average recoveries in the 4 chambers were $88,88,90$, and $89 \%$, respectively.

\section{Estimation of Daily $\mathrm{CH}_{4}$ Emissions Using LMD}

Two LMD units (Mini-Green Lmm-g; Tokyo Gas Engineering Solutions, Tokyo, Japan) were used. Measurement principle (tunable diode laser absorption spectroscopy) and the operation of the devices were described in detail by Chagunda et al. (2013) and Sorg et al. (2018). The duration of single measurements was set to $6 \mathrm{~min} / \mathrm{cow}$, and the distance between the LMD device and the cow's nostril was set to $1 \mathrm{~m}$. The measurements were conducted on each cow during the last $3 \mathrm{~d}$ of the 8-d sampling period, before and after each feeding event while the animals were standing. From each LMD measurement, the $\mathrm{CH}_{4}$ concentration (ppm $\times \mathrm{m}$; arithmetic mean of all peaks in a 6-min measurement) was calculated. Estimates of daily $\mathrm{CH}_{4}$ emissions by the LMD technique $\left(\mathrm{P}_{\mathrm{m} \text { LMD }} ; \mathrm{g} / \mathrm{d}\right)$ were obtained as described by Sorg et al. (2018). The 3-d $\mathrm{P}_{\mathrm{m} \text { LMD }}$ values were averaged across before feeding, after feeding, and overall.

\section{Recordings, Sampling, and Analysis of Feed, Feces, Urine, and Rumen Fluid}

Body weight was measured on a truck load scale (Waagen Döhrn GmbH \& Co. KG, Wesel, Germany) upon arrival and directly before and after the sampling period. Milk yield was recorded automatically. During the sampling period, samples from each milking (50 $\mathrm{mL}$ ) were separately conserved with bronopol. Eating and ruminating behavior were recorded on 3 consecutive days per cow during the sampling period, using RumiWatch (Itin + Hoch GmbH, Liestal, Switzerland) halters equipped with pressure sensors detecting jaw movements, acceleration sensors detecting head position, and data loggers. Data were differentiated by the software into eating, ruminating, and other activities (Rombach et al., 2018). During the sampling period, feed intake was measured daily from supply and leftovers on flat troughs with separations between cows, using electronic balances developed by Mettler-Toledo (Dübendorf, Switzerland). The leftovers were pooled per animal. Forage samples were taken once per week in the adaptation period and twice in the sampling period. Grass pellets and concentrate were sampled 3 times during the 23-d experiment. Samples were dried at $60^{\circ} \mathrm{C}$ to constant weight and ground to a particle size of $1 \mathrm{~mm}$ with a cutting mill. For concentrate samples, a centrifugal mill was used.

During the 8-d sampling period, all feces were collected on steel trays located below a grid at the end of the tie stall. Urine was collected separately from feces using urinals attached around the vulva and glued (Cyanolit 202, Panacol Elosol GmbH, Steinbach, Germany) onto hair and skin. Urine $\mathrm{pH}$ was maintained at $<3$ by the addition of $5 \mathrm{M} \mathrm{H}_{2} \mathrm{SO}_{4}$ to prevent ammonia volatilization. Feces and urine were weighed daily, and representative samples proportional to the amounts excreted were taken and frozen at $-20^{\circ} \mathrm{C}$. For the quantification of digesta retention time, 100-g samples of feces were collected $4,8,12,18,22,26,30,36,42$, $46,52,58,66,74,82,90,98,106,114,126,138$, and $150 \mathrm{~h}$ after application of a marker bolus. Baseline was determined by 3 samples taken on the day before bolus application. The markers used were Co-EDTA as solute marker and mordanted grass hay following Udén et al. (1980). For that process, the hay was cut in a cutting mill (MM180S, Fuchs-Mühlen, Vienna, Austria) to pass an 8 -mm screen. The cut hay was sequentially dry screened by shaking on sieves with mesh sizes of 3.55 , 
2,1 , and $0.5 \mathrm{~mm}$ to obtain 3 particle fractions of 8,5 , and $2 \mathrm{~mm}$, which were mordanted with Ce, La, and $\mathrm{Cr}$, respectively. For more details see Grandl et al. (2018). The samples of feces containing marker were dried at $60^{\circ} \mathrm{C}$ to constant weight and ground through a $1-\mathrm{mm}$ screen with a centrifugal mill.

Rumen fluid was collected on d 9 of the sampling period at $4 \mathrm{~h}$ after morning feeding via a stomach tube (SELEKT Pump and Collector, Nimrod Veterinary Products Ltd., Gloucestershire, UK). Two duplicate samples of $10 \mathrm{~mL}$ were obtained. Trichloroacetic acid was added to one for ammonia analysis and sulfuric acid to the other for VFA analysis. Samples were stored at $-20^{\circ} \mathrm{C}$.

Feeds and feces were analyzed according to standard procedures (AOAC International, 1995). Contents of $\mathrm{DM}$ and total ash were determined with a thermogravimetric device (TGA-701, Leco Corp., St. Joseph, MI; AOAC method 942.05). The OM was calculated as DM minus total ash. Nitrogen was assessed in feeds, nondried feces, and acidified urine on a $\mathrm{C} / \mathrm{N}$ analyzer (Type TruMac CN, Leco Cooperation; AOAC method 968.06). The CP was calculated as $6.25 \times \mathrm{N}$. Ether extract was determined with a Soxhlet extraction system (model B-811, Büchi, Flawil, Switzerland). Ash-corrected contents of NDF (AOAC method 2002.04; with heat-stable $\alpha$-amylase [Sigma-Aldrich, St. Louis, MO]) and ADF (AOAC method 973.18) in feeds and feces were determined using the Gerhardt Fibertherm FT 12 (Gerhardt GmbH and Co. KG, Königswinter, Germany). Determination of ADL in feed items was performed sequentially after ADF analysis by incubation in sulfuric acid (72\%) for $3 \mathrm{~h}$. Gross energy (GE) contents were measured in feeds and feces with a bomb calorimeter (C7000, IKA-Werke GmbH \& Co. KG, Staufen, Germany). The bronopol-conserved milk was analyzed for contents of fat, protein, and lactose using a Fourier transform infrared spectrophotometer (MilkoScan FT6000 Foss Electric) at SuisseLab AG (Zollikofen, Switzerland). The spectra obtained during this process were also used to determine $\mathrm{P}_{\mathrm{m} \text { MIR }}$. Milk protein was divided by 6.38 to calculate $\mathrm{N}$ content. The element concentrations in the Co-EDTA, the mordanted hay, and the feces were analyzed after wet ashing using inductively coupled plasma optical emission spectrometry (Optima 8000, Pekin Elmer, Rodgau, Germany). The markers contained (per kg DM) $32.8 \mathrm{~g}$ of $\mathrm{Cr}, 49.5 \mathrm{~g}$ of La, 41.5 $\mathrm{g}$ of Ce, and $151 \mathrm{~g}$ of Co. Rumen fluid ammonium was measured with a potentiometer equipped with a corresponding glass electrode (6.0506.100, Metrohm AG, Herisau, Switzerland) calibrated by using $\mathrm{NH}_{4} \mathrm{Cl}$ at $0.1,1$, and $10 \mathrm{~m} M$. The VFA were analyzed by HPLC (LaChrom, L-7000 series, Hitachi Ltd., Tokyo, Japan) with a UV detector.

\section{Calculations and Statistical Analysis}

Feed conversion efficiency (ECM/DMI), milk production efficiency (ECM/BW), and RFI (difference between observed and predicted DMI) were calculated as measures of efficiency. For RFI, the predicted DMI was calculated using Equation 1 of Gruber at al. (2004), which was developed based on measured DMI data recorded in Switzerland, Austria, and Germany, thus reflecting similar farming systems. This equation considered breed, lactation number, DIM, BW, milk yield, concentrate amount, and forage composition. The ECM $(\mathrm{kg} / \mathrm{d})$ was calculated as milk $(\mathrm{kg} / \mathrm{d}) \times[0.38 \times$ fat $(\%)+0.24 \times$ protein $(\%)+0.17 \times$ lactose $(\%)] / 3.14$ (Agroscope, 2019).

Fecal baseline marker concentrations were used to correct for individual animal background levels. Mean retention time (MRT) in the gastrointestinal tract (GIT) was computed for each marker according to Thielemans et al. (1978), as MRT GIT $=\left(\Sigma C_{i} \times t_{i-1, i}\right.$ $\left.\times \mathrm{dt}_{i}\right) /\left(\Sigma C_{i} \times \mathrm{dt}_{i}\right)$, where $t_{i-1, i}=$ mean time $(\mathrm{h})$ after application of markers of 2 subsequent samplings $i-1$ and i calculated as $t_{i-1}+\left(t_{i}-t_{i-1}\right) / 2, C_{i}=$ marker content in the fecal sample voided in the interval represented by time $t_{i}$ and $t_{i-1}$, and $\mathrm{d} t_{i}=$ sampling interval (h) of the respective sample calculated as $\left[\left(t_{i-1}-t_{i}\right)\right.$ $\left.+\left(t_{i}-t_{i-1}\right)\right] / 2$. The MRT of Co-EDTA in the reticulorumen (RR) was calculated following Grovum and Williams (1973) and that of the particles according to Huhtanen and Kukkonen (1995), as MRT RR particles = MRT GIT particles - (MRT GIT solute - MRT RR solute). Dry matter gut fill was calculated following Munn et al. (2015) and considering DMI, DM digestibility, and the MRT GIT of the 5-mm particle marker (La).

All statistical analyses were performed with $\mathrm{R}$ version 3.3.1 (R Core Team, 2018). As a measure for accuracy, Lin's concordance correlation coefficients $(\mathbf{C C C})$ were computed between the $\mathrm{CH}_{4}$ emission data measured and predicted, as well as linear regressions. Pearson correlation coefficients were calculated between $\mathrm{P}_{\mathrm{m}}$ and non- $\mathrm{CH}_{4}$ variables. Data from the 10 low and 10 high $Y_{m \text { RC }}$ cows were subjected to ANOVA performed with a linear mixed model using the nlme R-package (Pinheiro et al., 2017). Emission category (low, high), experimental block (run 1-7 with 4 cows, run 8 with 2 cows) and their interaction were fixed effects, and cow was the random effect. The same model was used for the MIR categorized $\mathrm{P}_{\mathrm{m}}$ data $\left(\mathrm{MIR}_{1}, \mathrm{MIR}_{3}\right.$ old and new, $\mathrm{MIR}_{4}$ old and new $\left., \mathrm{RC}, \mathrm{LMD}\right)$. Homogeneity of variances was checked with the Bartlett test and normality of the residuals with the Shapiro-Wilks test. To evaluate the accuracy of the prediction of $\mathrm{P}_{\mathrm{m} \text { MIR }}$, the root mean square error of prediction (RMSEP) for predicted $\mathrm{CH}_{4}$ 
$\left(\mathrm{MIR}_{3 \text { old }}\right.$ and $\left.\mathrm{MIR}_{3 \text { new }}\right)$ was also calculated according to Vanlierde et al. (2015).

\section{RESULTS}

\section{Categorization of Cows by MIR $\mathrm{CH}_{4}$ Predictions and Its Recovery by Measured $\mathrm{CH}_{4}$}

Based on the population screening, the groups of 159 low and 159 high $\mathrm{P}_{\mathrm{m} \text { MIR }}$ cows differed in each month during the entire 1.5-yr period of assessment (Figure $1 \mathrm{C})$, and this outcome was also observed during the course of the lactation (Figure 1D). The 2 groups of 15 cows selected for the on-station experiment also

A
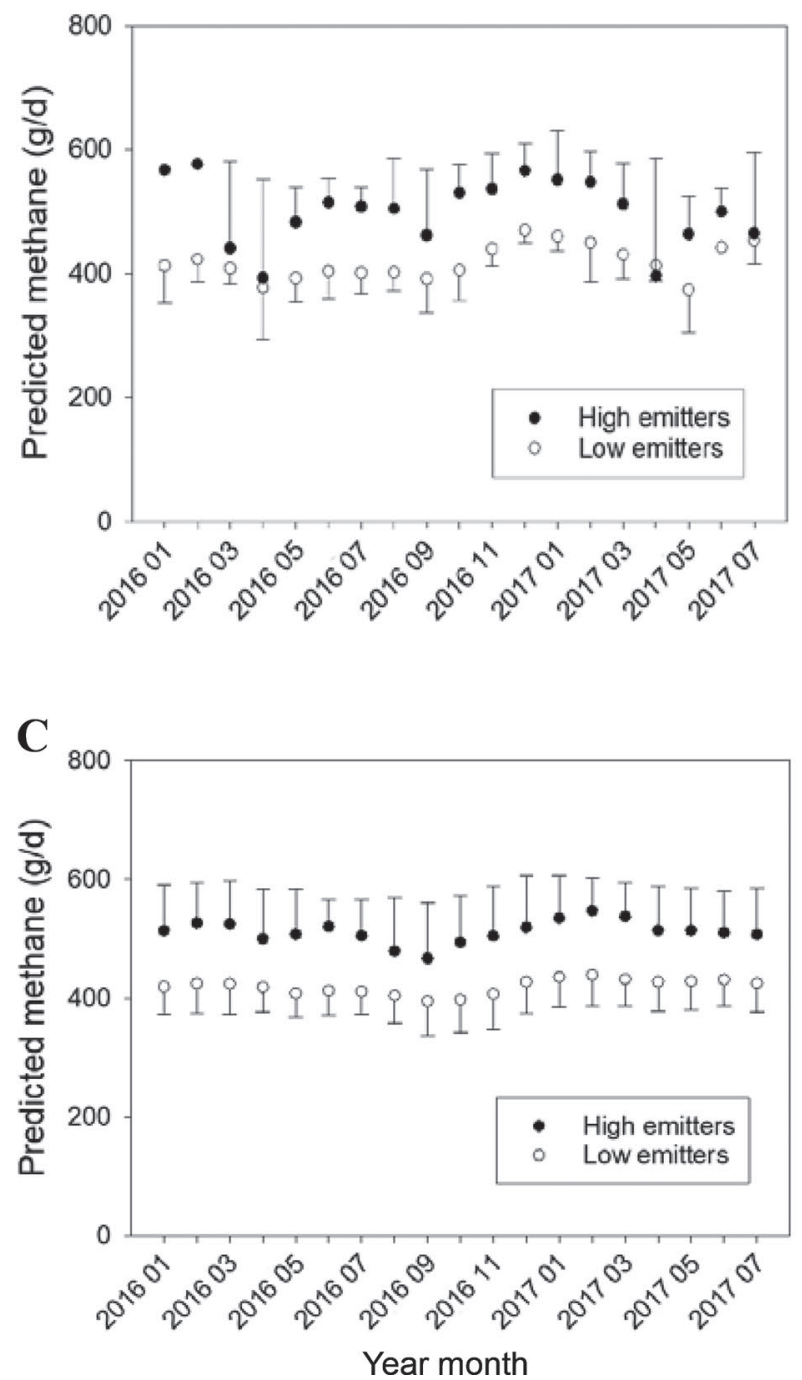

differed in almost every month and during lactation (Figures 1A and 1B). The characteristics of the cows in the experiment are given in Table 3. Accordingly, the average difference (high in relation to low $\mathrm{CH}_{4}$ emitting cows) in $\mathrm{P}_{\mathrm{m} \text { MIR }}$ was $16 \%$ (old equation) when determined directly before the start of the experiment on the home farm $\left(\mathrm{MIR}_{1}\right)$, and was $18 \%$ (old equation) and $10 \%$ (new equation) in spectra obtained on the day of arrival at the research station $\left(\mathrm{MIR}_{2}\right)$. The absolute $\mathrm{P}_{\mathrm{m} \text { MIR }}$ levels differed between the 3 assessments, especially in the high $\mathrm{P}_{\mathrm{m} \text { MIR }}$ cows. The 2 categories were similar in average DIM and milk yield.

Values for CCC $(P<0.01)$ in $\mathrm{P}_{\mathrm{m} \text { MIR }}$ were close across all time points $\left(\mathrm{MIR}_{1,3,4}\right)$ when using the old

\section{B}
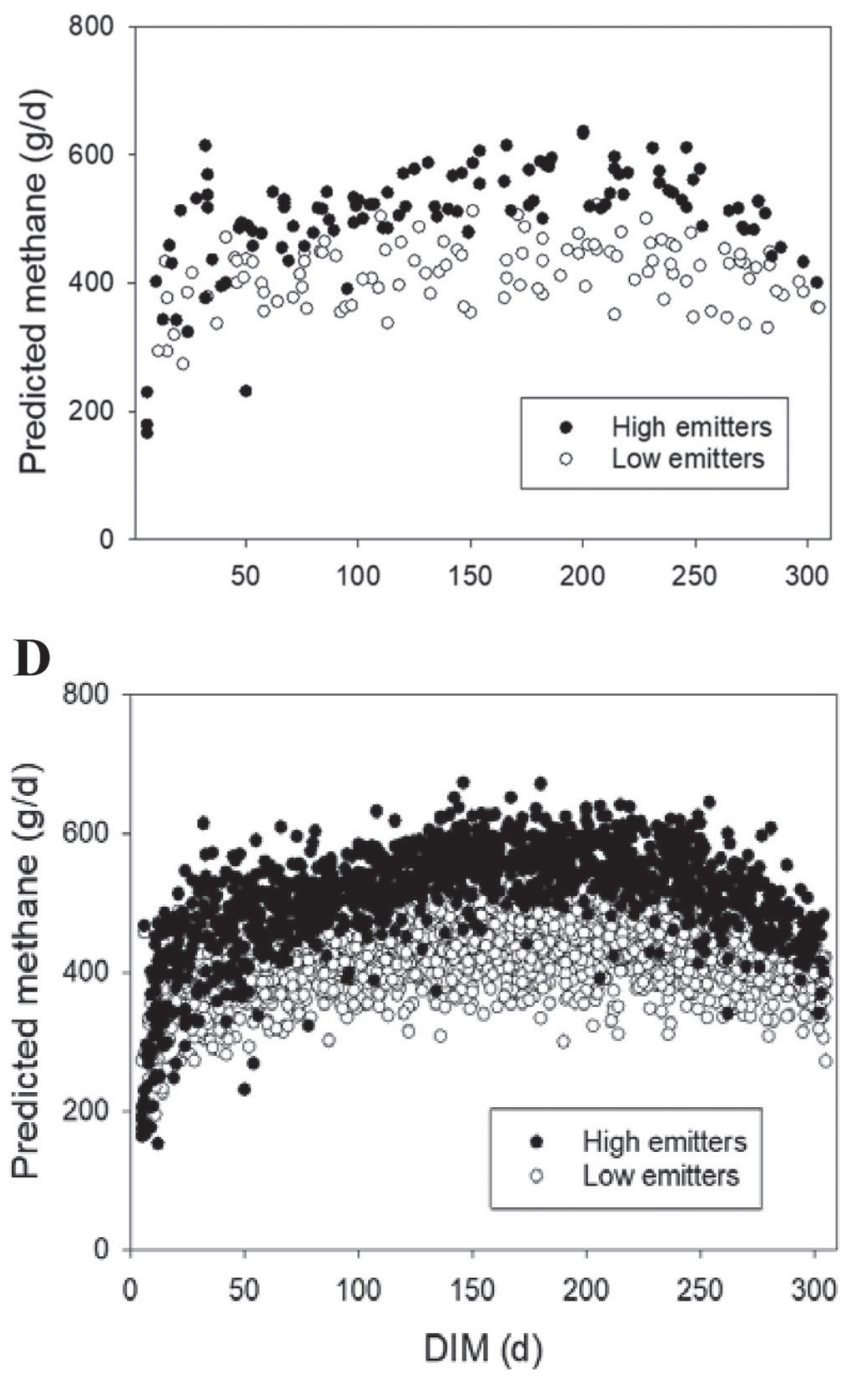

Figure 1. Methane production (g/d) before the experiment predicted from milk mid-infrared (MIR) spectra obtained in the 18 mo from January 2016 to July 2017 (means \pm SE; A and C: changes with calendar time; B and D: changes with progressing DIM) of either all lactating Brown Swiss cows identified as low and high methane emitters $(\mathrm{n}=2 \times 159$; upper and lower quartile of preselected cows; C and D) or the cows selected for the present experiment $(\mathrm{n}=2 \times 15$; $\mathrm{A}$ and $\mathrm{B})$. 
Table 3. Description of the experimental animals selected for presumed low and high $\mathrm{CH}_{4}$ emissions $\left(\mathrm{P}_{\mathrm{m}}\right)$ based on milk mid-infrared (MIR) spectra predictions before the experiment (arithmetic means \pm SD or ranges)

\begin{tabular}{|c|c|c|c|}
\hline \multirow[b]{2}{*}{ Item } & \multicolumn{2}{|c|}{ MIR- $\mathrm{CH}_{4}$ emission category } & \multirow{2}{*}{$\begin{array}{c}\text { Overall } \\
\text { characterization of } \\
\text { the cows }(\mathrm{n}=30)\end{array}$} \\
\hline & $\begin{array}{c}\text { Low } \\
(\mathrm{n}=15)\end{array}$ & $\begin{array}{c}\text { High } \\
(\mathrm{n}=15)\end{array}$ & \\
\hline \multicolumn{4}{|l|}{$\operatorname{Methane~}^{1}\left(\mathrm{P}_{\mathrm{m}} ; \mathrm{g} / \mathrm{d}\right)$} \\
\hline $\mathrm{MIR}_{1}{ }^{2}$ & $409 \pm 23$ & $507 \pm 36$ & $455 \pm 57$ \\
\hline $\mathrm{MIR}_{2}$ old $^{3}$ & $450 \pm 42$ & $529 \pm 28$ & $487 \pm 61$ \\
\hline $\mathrm{MIR}_{2 \text { new }}{ }^{3}$ & $411 \pm 26$ & $443 \pm 34$ & $426 \pm 54$ \\
\hline $\mathrm{BW}^{3}$ & $656 \pm 39$ & $637 \pm 39$ & $651 \pm 42$ \\
\hline $\mathrm{DIM}^{2}$ & $244 \pm 29$ & $238 \pm 31$ & $241 \pm 30$ \\
\hline Milk vield ${ }^{4}(\mathrm{~kg} / \mathrm{d})$ & $20.2 \pm 2.62$ & $20.7 \pm 2.8$ & $20.3 \pm 5.3$ \\
\hline $\mathrm{BW}$ range ${ }^{4}(\mathrm{~kg})$ & $570-740$ & $550-680$ & $570-740$ \\
\hline
\end{tabular}

${ }^{1} \mathrm{MIR}=$ methane emission predicted from mid-infrared spectra of milk samples analyzed. For further explanations see Table 2.

${ }^{2}$ Measured during last monthly milk performance recording before the start of the experiment (July 2017).

${ }^{3}$ Measured on the first day at the experimental station.

${ }^{4}$ Measured during the experimental period.

equation, and between the 2 time points assessed with the new equation $(P<0.001)$ (Table 4$)$. This result is illustrated through the regression analysis for the MIR assessments on the home farm and during the 8-d collection period (Figure 2A). The changes caused by using the new equation were moderate (Figure 2B). By contrast, no significant correlations were found between individual cow data from either RC or LMD values with the MIR predictions or between RC and LMD (Table 4, Figure 2C-F). Accordingly, relating $\mathrm{P}_{\mathrm{m} R \mathrm{RC}}$ with $\mathrm{P}_{\mathrm{m} \text { MIR3 ("old" and "new") by means of a linear }}$ regression did not result in significant relationships $\left(\mathrm{R}^{2}\right.$ old $=0.014, P=0.23 ; \mathrm{R}^{2}$ new $=0.026, P=0.19$ ). The RMSEP was smaller using RC data and $\mathrm{MIR}_{3 \text { new }}$ $(30.6 \mathrm{~g} / \mathrm{d})$ compared with using $\mathrm{RC}$ data and $\mathrm{MIR}_{3 \_ \text {old }}$
(48.1 g/d). No significant CCC was found between the 3 LMD-predicted $\mathrm{P}_{\mathrm{m}}$ variables (Table 4).

The categories established before the experiment $\left(\mathrm{MIR}_{1}\right)$ and those based on spectra obtained in the 8-d sampling period $\left(\mathrm{MIR}_{3}\right)$ were mostly different on average $(P<0.05$ to 0.01$)$ in $\mathrm{P}_{\mathrm{m} \text { MIR }}$ with any equation (old, new; Table 5). Using the new equation for MIR-based predictions largely reduced SE of the category means. Recategorization resulted in a certain regrouping of the 28 cows, with 1 cow each from low to high $\mathrm{P}_{\mathrm{m} \text { MIR }}$ and vice versa when moving from Categorization MIR1 $_{1}$

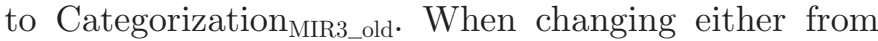
Categorization $_{\text {MIR1 }}$ to Categorization ${ }_{\text {MIR3 new }}$ or from Categorization $_{\text {MIR3 old }}$ to Cagetorization MIR3 new $_{\text {new }}, 3$ cows each were regrouped. Other than predicted, $\mathrm{P}_{\mathrm{m} \mathrm{RC}}$ and

Table 4. Lin's concordance correlation coefficients between different predictions and measurements of methane production $(\mathrm{g} / \mathrm{d} ; \mathrm{n}=28)^{1}$

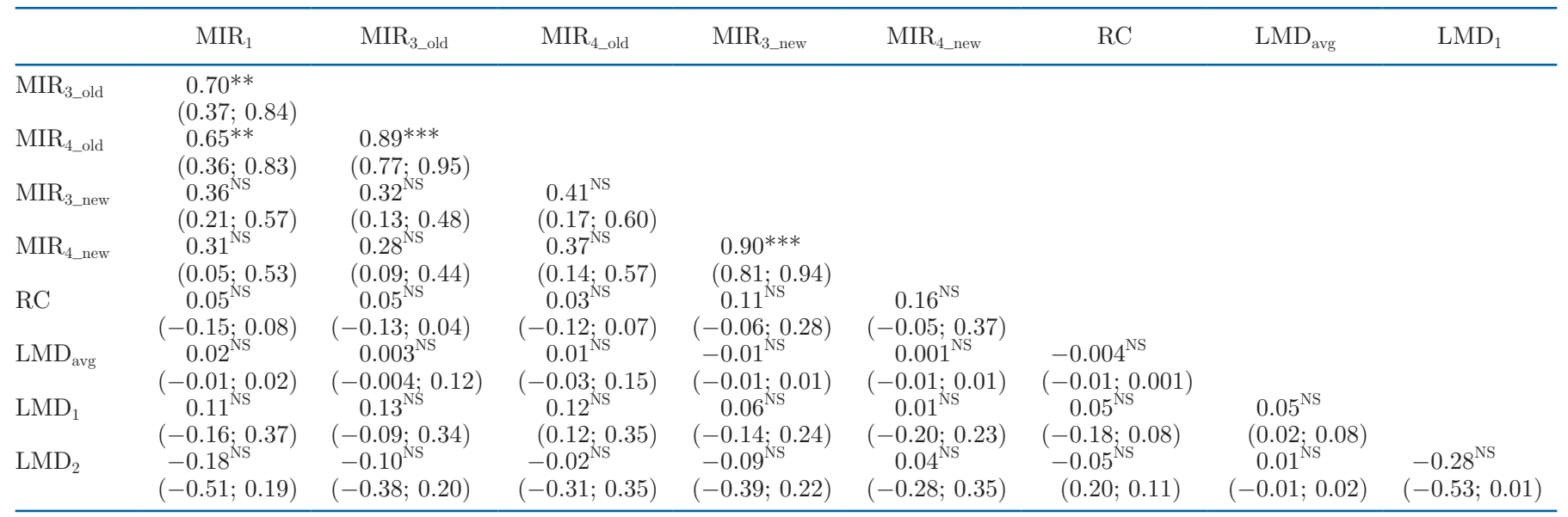

${ }^{1}$ Values in parentheses are $95 \%$ CI. MIR $=\mathrm{CH}_{4}$ values predicted by mid-infrared analysis (for further explanations see Table 2); $\mathrm{RC}=$ respiration chamber; LMD = laser methane detector $(1=$ used before feeding; $2=$ used after feeding; avg $=$ daily average $)$.

** $P<0.01 ; * * * P<0.001$. 
$\mathrm{P}_{\mathrm{m} \text { LMD }}$ levels measured in low and high $\mathrm{P}_{\mathrm{m} \text { MIR }}$ cows did not differ $(P>0.10$; Table 5$)$.

\section{Characteristics of Cows Categorized by the RC Results}

The animals were recategorized into low and high $\mathrm{CH}_{4}$ emitters based on their $\mathrm{Y}_{\mathrm{m} \text { DMI }}$ as measured by $\mathrm{RC}$ (Table 6). Group differences (high in relation to low $\mathrm{Y}_{\mathrm{m} \mathrm{RC}}$ ) accounted for 18, 21, 19, and $19 \%$ when $\mathrm{CH}_{4}$ was related to intakes of $\mathrm{DM}$, digestible $\mathrm{OM}$, digestible NDF, and GE, respectively $(P<0.01$ to 0.001$)$. The difference $(P=0.001)$ was even larger with $21 \%$ for $\mathrm{CH}_{4}$ emission intensity $\left(\mathbf{I}_{\mathrm{m}} ; \mathrm{CH}_{4} / \mathrm{ECM}\right)$, but not for $\mathrm{CH}_{4} / \mathrm{BW}$. The $\mathrm{P}_{\mathrm{m} \mathrm{RC}}$, in contrast, was not different between the categories, similar to the $\mathrm{P}_{\mathrm{m} \text { MIR }}$ averages obtained at 2 different time points and with 2 different equations. When relating $\mathrm{P}_{\mathrm{m} \text { MIR }}$ to measured DMI $\left(\mathrm{Y}_{\mathrm{m} \text { MIR DMI }}\right), \mathrm{Y}_{\mathrm{m} \text { RC }}$-categorized cows differed $(16 \%$; $P<0.05)$ with $\mathrm{MIR}_{1}$, and trends for such differences
A
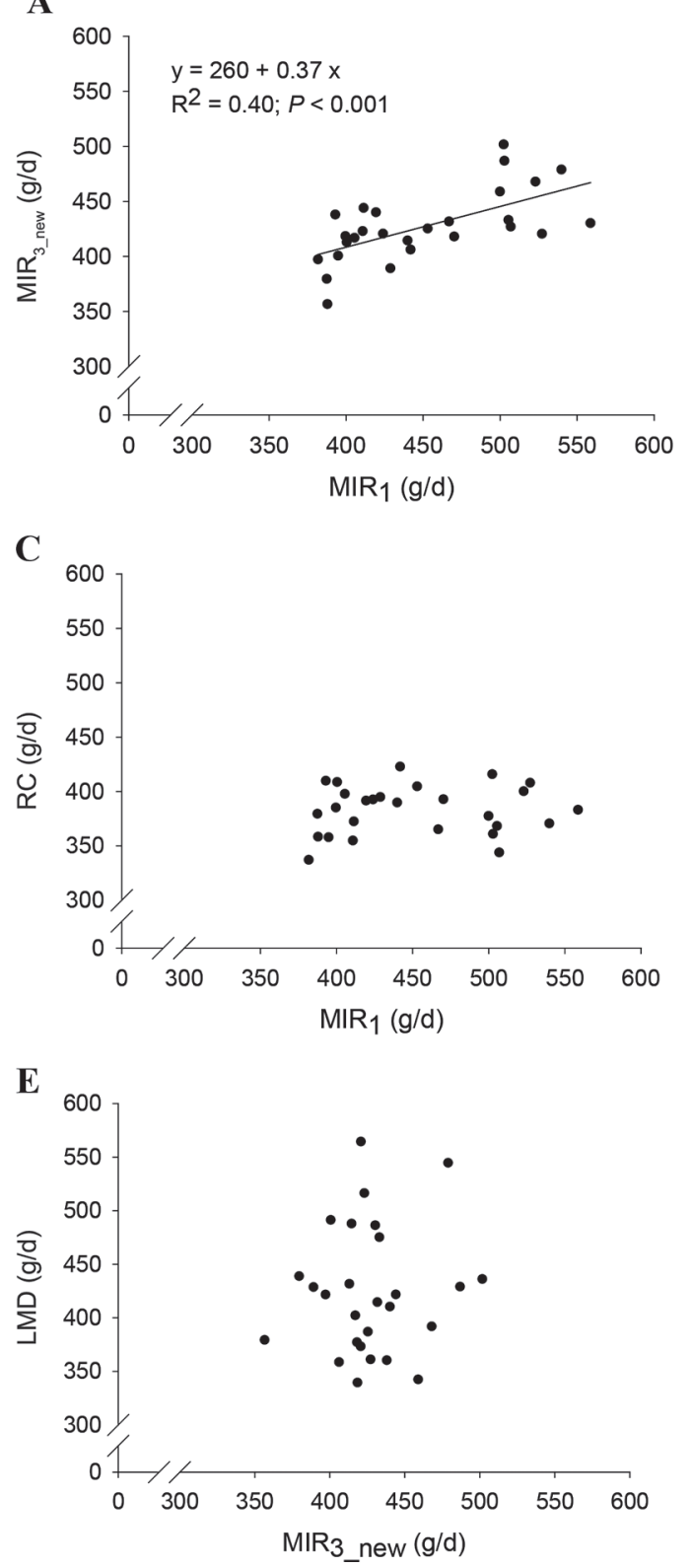

B

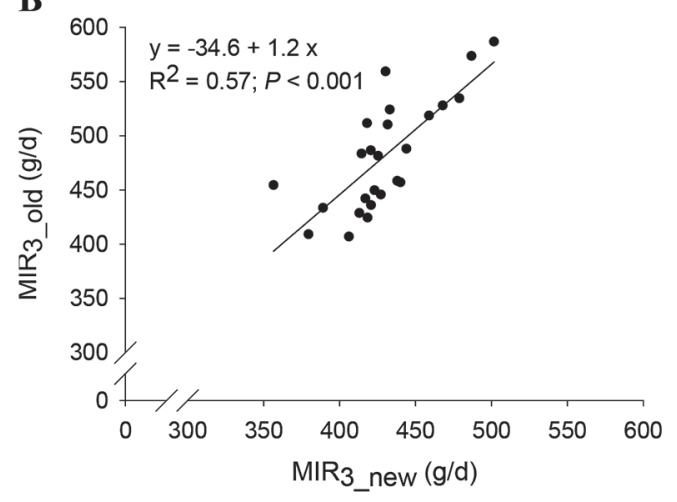

D
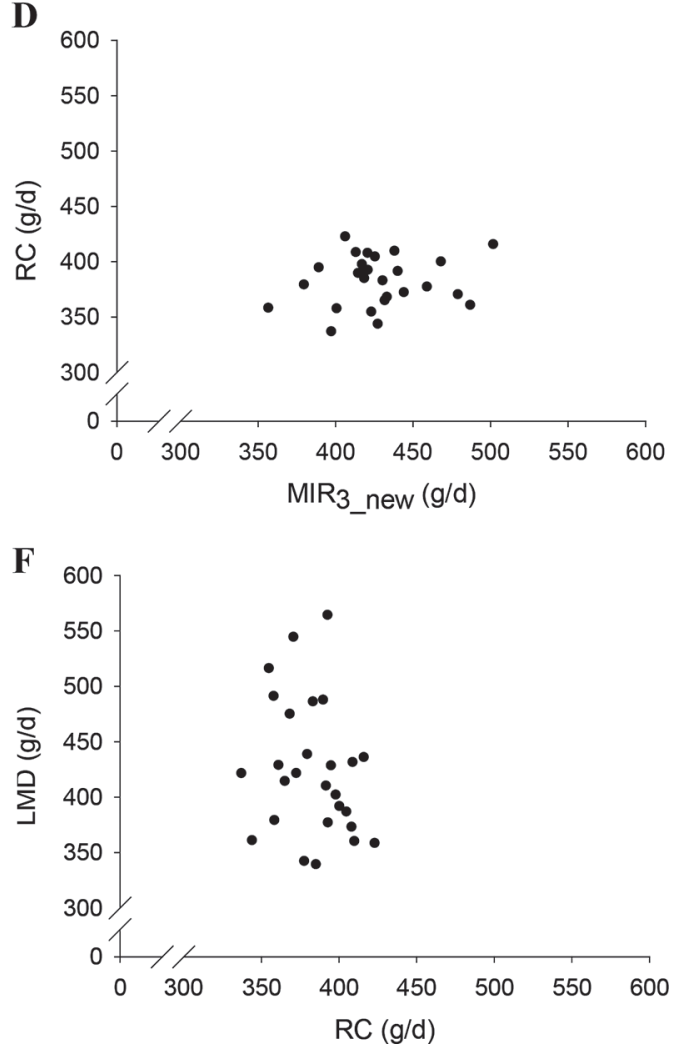

Figure 2. Relationships between individual cow $\mathrm{CH}_{4}$ production data (g/d) predicted by the milk mid-infrared (MIR) spectra obtained from the last milking before the experiment $\left(\mathrm{MIR}_{1}\right.$; July 2017$)$ and across the $8 \mathrm{~d}$ of sampling $\left(\mathrm{A}: \mathrm{MIR}_{3 \text { new }}\right.$ and $\mathrm{B}$ : MIR $\mathrm{M}_{3 \text { old }}$; using the newest and the first available equation, respectively) and those measured in respiration chambers (RC; on sampling d 9; C, D) and with the laser methane detector (LMD; across the last $3 \mathrm{~d}$ within $8 \mathrm{~d}$ of sampling; E); and those measured in RC and with LMD (F). 
(13 and 18\%; $P<0.10$ ) were found using $\mathrm{MIR}_{3}$ (old and new equations). Group differences in LMD results before and after feeding were reversed, leading to almost the same average $\mathrm{P}_{\mathrm{m} \text { LMD }}$ in the 2 categories. In addition, $Y_{m}$ DMI did not differ between groups when measured with LMD.

Compared with the high $\mathrm{Y}_{\mathrm{m} R \mathrm{RC}}$ cows, the low $\mathrm{Y}_{\mathrm{m} R \mathrm{RC}}$ cows were characterized by a higher DMI $(+11 \%$; $P<$ $0.01)$ and a higher ECM yield $(+27 \% ; P<0.05)$ (Table 7). The diets as consumed contained $10.0 \pm 1.5 \%$ and $7.4 \pm 0.6 \%$ concentrate for low and high $\mathrm{Y}_{\mathrm{m} \mathrm{RC}}$ cows, respectively. The low $\mathrm{Y}_{\mathrm{m} \text { RC }}$ cows were higher $(P$ $<0.05)$ in ECM/BW compared with the high $\mathrm{Y}_{\mathrm{m} \mathrm{RC}}$ cows. The RFI was higher $(P<0.05)$ for low compared with high $Y_{m}$ RC cows. Cow categories did not differ in daily eating and ruminating times; total-tract apparent digestibility of nutrients; and balance, losses, and utilization of $\mathrm{N}$ for milk protein formation (milk N, \% of $\mathrm{N}$ intake or digested $\mathrm{N}$ intake). The low $\mathrm{Y}_{\mathrm{m}} \mathrm{RC}$ cows had a different VFA pattern compared with the high $\mathrm{Y}_{\mathrm{m} \mathrm{RC}}$ cows, with higher proportions of propionate $(P$ $<0.01)$, lower proportions of acetate $(P<0.05)$, and a consequently lower acetate-to-propionate ratio $(P<$ $0.001)$. Ruminal ammonia concentration and most variables describing MRT of the digesta in RR and GIT did not differ between categories. Only GIT MRT of small particles was shorter $(P<0.05)$ in low compared with high $\mathrm{Y}_{\mathrm{m} \text { RC }}$ cows, associated with a slightly higher $(P<$ 0.05) DM gut fill.

The data on $\mathrm{P}_{\mathrm{m} R \mathrm{RC}}$ correlated with $\mathrm{DMI}$ and $\mathrm{N}$ intake, digestibility of $\mathrm{OM}$ and NDF, urinary $\mathrm{N}$ losses, propionate, isobutyrate, and isovalerate proportions of total VFA, as well as acetate-to-propionate ratio $(P<0.05$ to 0.01 ; Table 7$)$. In addition, trends for Pearson correlations $(P<0.10)$ were apparent in RFI, CP digestibility $(P<0.05-0.01)$, and milk $\mathrm{N}$ relative to intake of digested N. Only a few correlations were found between $\mathrm{P}_{\mathrm{m} \text { MIR }}$ and these variables $(P<0.05-0.01)$. These included ECM per unit of DMI and milk $\mathrm{N}$ proportion of intake of $\mathrm{N}$ and digested $\mathrm{N}$ ( $\mathrm{MIR}_{3 \_ \text {old }}$ only).

\section{DISCUSSION}

The current study attempted to confirm the usefulness of predictions of daily $\mathrm{CH}_{4}$ emissions based on MIR spectra of milk samples or estimates of daily $\mathrm{CH}_{4}$ emissions made using LMD detectors to predict actual daily $\mathrm{CH}_{4}$ emissions of dairy cows. Our study showed that the predictions based on currently available equations derived from MIR spectra as well as the estimates based on short-term measurements made with the LMD devices did not have a close phenotypical correlation with the measured values. This outcome does not necessarily exclude the presence of genetic

Table 5. Methane production $\left(\mathrm{P}_{\mathrm{m}}, \mathrm{g} / \mathrm{d}\right)$ of cows categorized into low $(\mathrm{n}=15)$ or high $(\mathrm{n}=13)$ emitters based on values predicted from milk mid-infrared (MIR) spectra obtained before or during the experiment (LSM \pm $\mathrm{SE})^{1}$

\begin{tabular}{|c|c|c|c|c|}
\hline \multirow{2}{*}{$\begin{array}{l}\text { Milk spectra } \\
\text { database }\end{array}$} & \multirow{2}{*}{$\begin{array}{l}\text { Categorization } \\
\text { based on }\end{array}$} & \multicolumn{2}{|c|}{ MIR emission category } & \multirow[b]{2}{*}{$P$-value } \\
\hline & & Low & High & \\
\hline \multirow[t]{3}{*}{$\mathrm{MIR}_{1}$} & $\mathrm{MIR}_{1}$ & $407 \pm 14.1$ & $501 \pm 14.5$ & 0.002 \\
\hline & $\mathrm{MIR}_{3 \text { _old }}$ & $417 \pm 11.1$ & $492 \pm 10.7$ & 0.010 \\
\hline & $\mathrm{MIR}_{3 \_ \text {new }}$ & $422 \pm 17.1$ & $479 \pm 13.7$ & 0.14 \\
\hline \multirow[t]{3}{*}{$\mathrm{MIR}_{3 \_ \text {old }}$} & $\mathrm{MIR}_{1}$ & $486 \pm 55.6$ & $563 \pm 55.2$ & 0.002 \\
\hline & $\mathrm{MIR}_{3 \text { _old }}$ & $477 \pm 48.2$ & $561 \pm 47.8$ & 0.007 \\
\hline & $\mathrm{MIR}_{3 \text { new }}$ & $526 \pm 85.5$ & $587 \pm 84.6$ & 0.023 \\
\hline \multirow[t]{3}{*}{$\mathrm{MIR}_{4 \_ \text {old }}$} & $\mathrm{MIR}_{1}$ & $550 \pm 87.4$ & $622 \pm 86.2$ & 0.004 \\
\hline & $\mathrm{MIR}_{3 \_ \text {old }}$ & $535 \pm 83.7$ & $611 \pm 82.9$ & 0.020 \\
\hline & $\mathrm{MIR}_{3 \_ \text {new }}$ & $556 \pm 103.2$ & $603 \pm 102.1$ & 0.057 \\
\hline \multirow[t]{3}{*}{$\mathrm{MIR}_{3 \_ \text {new }}$} & $\mathrm{MIR}_{1}$ & $448 \pm 7.9$ & $411 \pm 7.0$ & 0.029 \\
\hline & $\mathrm{MIR}_{3 \text { old }}$ & $447 \pm 7.6$ & $411 \pm 7.9$ & 0.050 \\
\hline & $\mathrm{MIR}_{3 \_ \text {new }}$ & $405 \pm 6.5$ & $451 \pm 6.3$ & 0.002 \\
\hline \multirow{3}{*}{$\mathrm{MIR}_{4 \_ \text {new }}$} & $\mathrm{MIR}_{1}$ & $441 \pm 9.5$ & $403 \pm 8.5$ & 0.080 \\
\hline & $\mathrm{MIR}_{3 \_ \text {old }}$ & $440 \pm 9.2$ & $404 \pm 9.5$ & 0.14 \\
\hline & $\mathrm{MIR}_{3 \_ \text {new }}$ & $391 \pm 8.7$ & $447 \pm 7.2$ & 0.005 \\
\hline \multirow[t]{3}{*}{$\mathrm{RC}$} & $\mathrm{MIR}_{1}$ & $384 \pm 5.7$ & $382 \pm 6.4$ & 0.24 \\
\hline & $\mathrm{MIR}_{3 \_ \text {old }}$ & $386 \pm 6.2$ & $385 \pm 5.9$ & 0.56 \\
\hline & $\mathrm{MIR}_{3 \_ \text {new }}$ & $380 \pm 6.5$ & $385 \pm 6.6$ & 0.72 \\
\hline \multirow[t]{3}{*}{$\mathrm{LMD}^{2}$} & $\mathrm{MIR}_{1}$ & $423 \pm 16.5$ & $426 \pm 18.5$ & 0.95 \\
\hline & $\mathrm{MIR}_{3 \text { old }}$ & $416 \pm 18.4$ & $428 \pm 17.7$ & 0.60 \\
\hline & $\mathrm{MIR}_{3 \text { nnew }}$ & $429 \pm 17.5$ & $426 \pm 18.0$ & 0.47 \\
\hline
\end{tabular}

${ }^{1} \mathrm{MIR}=$ values predicted by mid-infrared analysis (for further explanations see Table 2 ); $\mathrm{RC}=$ respiration chamber; LMD = laser methane detector.

${ }^{2}$ Measurements in $\mathrm{ppm} \times \mathrm{m}$ were converted to $\mathrm{g} / \mathrm{d}$ using the regression of Sorg et al. (2018). 
Table 6. Methane emission of cows categorized into low or high $\mathrm{CH}_{4}$ emitters $(\mathrm{n}=2 \times 10)$ based on methane yield per unit of DMI $\left(\mathrm{Y}_{\mathrm{m}}\right)$ measured in the respiration chambers $(\mathrm{RC} ; \mathrm{LSM} \pm \mathrm{SE})^{1}$

\begin{tabular}{|c|c|c|c|}
\hline \multirow[b]{2}{*}{ Item } & \multicolumn{2}{|c|}{ Emission category } & \multirow[b]{2}{*}{$P$-value } \\
\hline & Low $Y_{\mathrm{m} \mathrm{RC}}$ & High $\mathrm{Y}_{\mathrm{m} \mathrm{RC}}$ & \\
\hline \multicolumn{4}{|l|}{ Respiration chamber } \\
\hline Methane production $\left(\mathrm{P}_{\mathrm{m}} ; \mathrm{g} / \mathrm{d}\right)$ & $379 \pm 6.9$ & $391 \pm 6.5$ & 0.22 \\
\hline \multicolumn{4}{|l|}{ Methane yield $\left(\mathrm{Y}_{\mathrm{m}}\right)$} \\
\hline $\mathrm{g} / \mathrm{kg}$ of DMI $\left(\mathrm{Y}_{\mathrm{m} \text { DMI }}\right)$ & $21.7 \pm 0.35$ & $25.6 \pm 0.33$ & $<0.001$ \\
\hline $\mathrm{g} / \mathrm{kg}$ of digestible OM & $34.6 \pm 0.71$ & $41.7 \pm 0.66$ & $<0.001$ \\
\hline $\mathrm{g} / \mathrm{kg}$ of digestible NDF & $104 \pm 3.8$ & $124 \pm 3.6$ & 0.003 \\
\hline$\%$ of gross energy $\left(\mathrm{Y}_{\mathrm{m} \mathrm{GE}}\right)$ & $6.77 \pm 0.129$ & $8.04 \pm 0.134$ & $<0.001$ \\
\hline \multicolumn{4}{|l|}{ Methane emission intensity $\left(\mathrm{I}_{\mathrm{m}}\right)$} \\
\hline per ECM (g/kg; I $\left.\mathrm{m}_{\mathrm{ECM}}\right)$ & $16.6 \pm 1.15$ & $21.1 \pm 1.09$ & 0.001 \\
\hline per BW $(\mathrm{g} / \mathrm{kg})$ & $0.60 \pm 0.022$ & $0.59 \pm 0.023$ & 0.81 \\
\hline \multicolumn{4}{|l|}{ MIR predictions } \\
\hline $\mathrm{MIR}_{1}\left(\mathrm{~g} / \mathrm{d} ; \mathrm{P}_{\mathrm{m}}\right)$ & $473 \pm 20.0$ & $483 \pm 18.8$ & 0.97 \\
\hline $\mathrm{MIR}_{3 \_ \text {old }}\left(\mathrm{g} / \mathrm{d} ; \mathrm{P}_{\mathrm{m}}\right)$ & $453 \pm 19.0$ & $450 \pm 17.9$ & 0.58 \\
\hline $\operatorname{MIR}_{3 \_ \text {new }}\left(\mathrm{g} / \mathrm{d} ; \mathrm{P}_{\mathrm{m}}\right)$ & $412 \pm 23.5$ & $415 \pm 24.0$ & 0.66 \\
\hline $\mathrm{MIR}_{1}\left(\mathrm{~g} / \mathrm{kg}\right.$ of DMI; $\left.\mathrm{Y}_{\mathrm{m}}\right)$ & $27.2 \pm 1.45$ & $31.6 \pm 1.37$ & 0.044 \\
\hline $\mathrm{MIR}_{3 \_ \text {old }}(\mathrm{g} / \mathrm{kg}$ of DMI; Y Y DMI $)$ & $26.1 \pm 1.39$ & $29.5 \pm 1.32$ & 0.090 \\
\hline $\mathrm{MIR}_{3 \_ \text {new }}\left(\mathrm{g} / \mathrm{kg}\right.$ of DMI; $\left.\mathrm{Y}_{\mathrm{m} \text { DMI }}\right)$ & $23.5 \pm 1.04$ & $27.8 \pm 1.08$ & 0.058 \\
\hline \multicolumn{4}{|l|}{ Laser methane detector ${ }^{2}$} \\
\hline Before feeding $(\mathrm{g} / \mathrm{d})$ & $384 \pm 39.2$ & $445 \pm 37.7$ & 0.48 \\
\hline After feeding $(\mathrm{g} / \mathrm{d})$ & $455 \pm 17.1$ & $412 \pm 17.4$ & 0.051 \\
\hline Average $\left(\mathrm{g} / \mathrm{d} ; \mathrm{P}_{\mathrm{m}}\right)$ & $422 \pm 22.0$ & $414 \pm 20.7$ & 0.77 \\
\hline Average (g/kg of DMI; $\left.\mathrm{Y}_{\mathrm{m} \text { DMI }}\right)$ & $24.3 \pm 1.63$ & $27.0 \pm 1.54$ & 0.26 \\
\hline
\end{tabular}

correlations, and further developed MIR spectra based equations might perform better. An in-depth investigation of potential factors of influence from ingestion and digestion that may cause $\mathrm{CH}_{4}$ emissions to differ among animals was carried out. In addition, the utility of the LMD technique was assessed. For both the MIR-based prediction and the LMD spot-sampling measurements, the RC technique was used as a reference method because it captures total $\mathrm{CH}_{4}$ emissions and is generally considered highly accurate. Indeed, the current results found with RC are highly plausible, which can be concluded from comparing levels of $\mathrm{P}_{\mathrm{m} R \mathrm{RC}}, \mathrm{Y}_{\mathrm{m} \text { RC DMI }}$, and $Y_{m R C ~ G E}$ with published data and from the expected significant positive relationships between $\mathrm{P}_{\mathrm{m} R \mathrm{RC}}$ and DMI, apparent fiber digestibility, and ruminal acetateto-propionate ratio (e.g., Niu et al., 2018).

\section{Robustness and Accuracy of the $\mathrm{CH}_{4}$ Prediction from Milk MIR Spectra}

Among the MIR-based prediction methods intended to be implemented into breeding schemes, the Belgian approach (Vanlierde et al., 2015, 2016, 2018) is probably the most developed because a high number of $\mathrm{CH}_{4}$ measurements and different diets are considered. Shetty et al. (2017) also attempted to predict $\mathrm{CH}_{4}$ via $\mathrm{P}_{\mathrm{m} \text { MIR }}$ by using reference data obtained from a nondispersive infrared analyzer installed (sniffer) in an automated milking system. Good agreement existed between this sniffer method and RC measurements (Garnsworthy et al., 2012a). However, when using the full milk MIR spectra and including DIM, the correlations were clearly lower with the sniffer method compared with those described by the Belgian group (Shetty et al., 2017). The Belgian equation was at first based on data derived from the $\mathrm{SF}_{6}$ method, but $\mathrm{RC}$ data were included later. This inclusion reduced the $\mathrm{R}^{2} \mathrm{c}$ from 0.74 to 0.66 (old equation used in the present study), but enhanced the applicability by generating additional variability (Vanlierde et al., 2016, 2018). Including more RC-based $\mathrm{P}_{\mathrm{m}}$ data in the most recent equation (new equation) improved the $\mathrm{R}^{2} \mathrm{c}$ to 0.68 .

The MIR predictions developed by Vanlierde et al. (2015), which were based on $\mathrm{SF}_{6}$ data, had shown a good correlation to a reference data set $\left(\mathrm{R}^{2} \mathrm{c}=0.75\right)$. Further, when predicted $\mathrm{CH}_{4}$ emissions were compared with RC-based measurements from an external data set, the correlation was still moderate $(\mathrm{r}=0.48)$. The SECV of a refined equation using $\mathrm{SF}_{6}$ and $\mathrm{RC}$ was $61 \mathrm{~g} / \mathrm{d}$. As the correlation is highly dependent on the distribution of the considered data set, the error of prediction also needs to be considered when evaluating the performance of a method. Additionally, prediction equations have known errors to consider. For the equation of Vanlierde et al. (2018), the SECV was $47 \mathrm{~g} / \mathrm{d}$ for a RC-based prediction and $70 \mathrm{~g} / \mathrm{d}$ for a $\mathrm{SF}_{6}$-based 
prediction. As a lower SECV indicates that the equation is closer to actual values (Vanlierde et al., 2018), the new equation was an improvement compared with the $\mathrm{SF}_{6}$-based equation. The RMSEP can be used to evaluate the predictive ability of the obtained calibration models (Shetty et al., 2017). Indeed, the RMSEP decreased from 48 to $31 \mathrm{~g} / \mathrm{d}$ when $\mathrm{MIR}_{3 \_ \text {new }}$ was used instead of $\mathrm{MIR}_{3 \text { old }}$. This RMSEP of the new equation is even lower than the known errors established during calibration and cross-validation processes.
To be useful for breeding purpose, the genetic variability of a trait among cows has to persist over time and different feeding regimens (Pinares-Patiño et al., 2011). The prediction equation indeed turned out to be robust over different countries, feeding regimens, and measurement techniques (Vanlierde et al., 2016, 2018). Persistence was also observed for the cohort of 318 cows of the present study when MIR spectra were followed across 1.5 yr. A suitable equation also has to consider that the $\mathrm{P}_{\mathrm{m}}$ of dairy cows changes over the course of

Table 7. Variables characterizing intake, performance, and digestion of cows categorized into low or high $\mathrm{CH}_{4}$ emitters $(\mathrm{n}=2 \times 10)$ based on $\mathrm{CH}_{4}$ yield per unit of DMI $\left(\mathrm{Y}_{\mathrm{m}}\right)$ measured in the respiration chambers (RC; $\mathrm{LSM} \pm \mathrm{SE}$ ) and correlations of these variables $(\mathrm{n}=28)$ with methane production $(\mathrm{g} / \mathrm{d}$ ) measured with $\mathrm{RC}$ and predicted with MIR based on first available (old) and further developed equation (new)

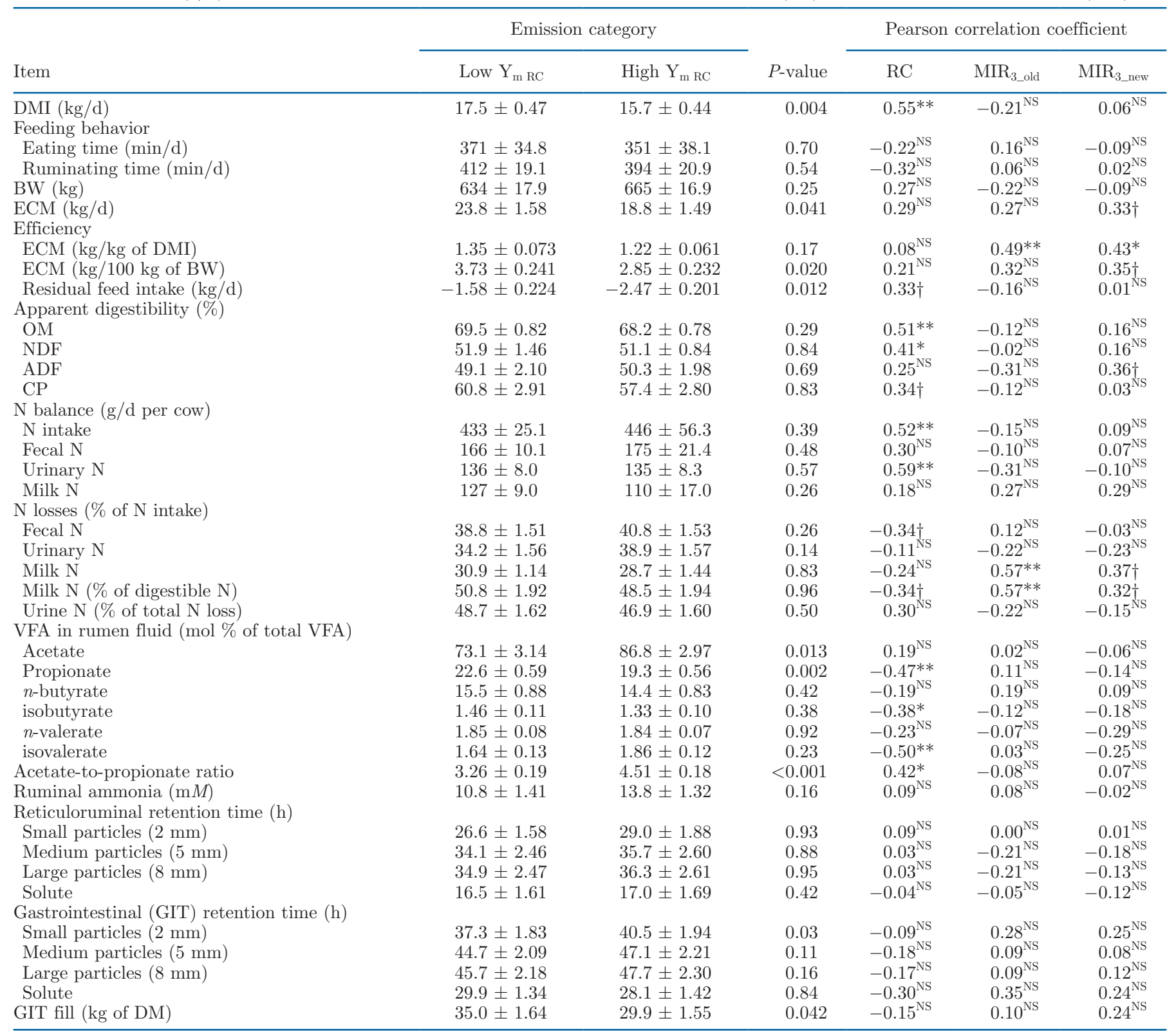

${ }^{*} P<0.05^{* *} P<0.01 ; \nmid P<0.10$. 
the lactation (Garnsworthy et al., 2012a). The $\mathrm{P}_{\mathrm{m} \text { MIR }}$ equation developed by Vanlierde et al. (2016) therefore considers DIM. Indeed, a biologically reasonable change in predicted $\mathrm{P}_{\mathrm{m} \text { MIR }}$ with DIM was found for both the 318 and the 30 cows. This change was also observed by Garnsworthy et al. (2012a) in an automated milking system fitted with an infrared sensor. To further exclude bias caused by DIM, we considered only cows with $\geq 5$ milk performance records obtained at different DIM when selecting the experimental cows.

Despite the good performance of the Belgian prediction equation (Vanlierde et al., 2018), especially in its newest version (unpublished), with respect to RMSEP and the biological meaningful change in $\mathrm{CH}_{4}$ emission over the course of the lactation (Figure 1C), the relationship (CCC) of the predicted with the $\mathrm{RC}$ data in the present study was weak. Different from a previous assessment on a single herd using GreenFeed instead of RC as standard method (Denninger et al., 2019), the low MIR predicting ability in our study also concerned categorization and not only that of individual cow values. The MIR predicting ability of category differences was better when the $2 \times 10$ cows were categorized retrospectively by using $\mathrm{RC}$ data. When $\mathrm{P}_{\mathrm{m} R \mathrm{RC}}$ and $\mathrm{P}_{\mathrm{m} \text { MIR }}$ were related to DMI, the differences were in a similar direction, and $\mathrm{P}_{\mathrm{m} \text { MIR }}$ was consistent across different stages of refinement of the prediction equation. However, none of the anticipated correlations of $\mathrm{P}_{\mathrm{m} \text { MIR }}$ with DMI, NDF digestibility, and ruminal VFA pattern were apparent. Also, the average $\mathrm{P}_{\mathrm{m} \text { MIR }}$ level predicted was too high (amounting to 9.9 and $9.3 \%$ of GE in high $\mathrm{Y}_{\mathrm{m} \text { MIR }}$ cows, predicted with $\mathrm{MIR}_{1}$ and $\left.\mathrm{MIR}_{3 \text { _old }}\right)$. This result clearly exceeded the default value of the IPCC (2006) of $6.5 \%$, which may have been due to including data from cows beyond the range of $\mathrm{P}_{\mathrm{m}}$ of 350 to $450 \mathrm{~g} / \mathrm{d}$ in the reference data set for the equation by Vanlierde et al. (2016). With further refinement of the equation $\left(\mathrm{MIR}_{3 \_ \text {new }}\right)$, the predicted $\mathrm{Y}_{\mathrm{m}}$ was lower, with $8.5 \%$ of GE. The number of animals used for the development of the equation whereby $\mathrm{CH}_{4}$ was measured by RC was still limited, but this cohort only included cows for which strong scrutiny or preselection against unusual animals or measurements had been practiced. This could also be a reason why the difference in $\mathrm{P}_{\mathrm{m} \text { MIR }}$ did not exceed $20 \%$ between low and high $\mathrm{P}_{\mathrm{m} \text { MIR }}$ cows and why the MIR prediction equations did not clearly discriminate between the categories distinguished by RC. However, the main goal of the present study was to recover the variability observed by MIR spectra on farm $\left(\mathrm{P}_{\mathrm{m} \text { MIR }}\right)$ by means of $\mathrm{RC}$ measurements, which was not successful. The findings based on the present data set support the claim of van Gastelen and Dijkstra (2016) that MIR data alone might be insufficient for a reliable prediction, at least to distinguish between ani- mals that are not at extremes in their $\mathrm{CH}_{4}$ emission levels. In this context, MIR spectra might not sufficiently predict indicative milk fatty acids related to processes associated with $\mathrm{CH}_{4}$ formation. van Gastelen and Dijkstra (2016) suggested that the MIR-based prediction might be improved by implementing more factors, such as milk yield, DMI, and others. However, care has to be taken against giving the correlated factors included too much weight in the equation, which would diminish the weight of the milk spectral information. Further improvements can be expected from continuing to develop the equation by adding new data of interest.

One other important drawback of the MIR-based predictions is that they currently only aim at absolute $\mathrm{CH}_{4}$ production and not at $\mathrm{CH}_{4}$ yield or $\mathrm{CH}_{4}$ emission intensity. However, the latter might be easily implemented because the milk recording events also provide data on milk yield. Currently, the knowledge of genetic correlations between different $\mathrm{CH}_{4}$ proxies and reference $\mathrm{CH}_{4}$ values is extremely limited.

\section{Accuracy of the $\mathrm{CH}_{4}$ Measurement with the LMD}

The LMD has been shown to be potentially useful in fast phenotyping the $\mathrm{P}_{\mathrm{m}}$ of cows under some circumstances because measurements require only a few minutes per cow (Sorg et al., 2018). The circadian pattern of $\mathrm{P}_{\mathrm{m}}$ is mainly driven by feed intake as determined by Bell et al. (2018) in a study of cows in a freestall barn. We therefore measured $\mathrm{P}_{\mathrm{m} \text { LMD }}$ before and after feeding. We found the expected lower $\mathrm{P}_{\mathrm{m}}$ before feeding, but only in the low $\mathrm{Y}_{\mathrm{m} R \mathrm{RC}}$ group. It is possible that, for a short time, low $\mathrm{CH}_{4}$ emitters have greater postfeeding emissions due to particularly effective fermentation, whereas greater "basal" (prefeeding) emissions lead to the overall higher emissions of high $\mathrm{CH}_{4}$ emitters. In this situation, the LMD technique may indeed be able to detect differences in $\mathrm{P}_{\mathrm{m}}$ caused by feeding events, as shown earlier by Sorg et al. (2017), but it also means that no reliable categorization may be possible with LDM values obtained after feeding. Chagunda (2013) reported a positive relationship between LMD and RC data and concluded that the LMD would rank cows for $\mathrm{P}_{\mathrm{m}}$ in a very similar way. When compared with the GreenFeed system and 2 different infrared sensors installed in an automatic milking system, the LMD method ranked cows similarly with respect to their $\mathrm{P}_{\mathrm{m}}$ (Sorg et al., 2018). Nevertheless, we found no correlation of any of the LMD measurements with the RC data (nor with any MIR prediction) despite repeating measurements over $3 \mathrm{~d}$. This outcome coincides with the report of low agreement by Ricci et al. (2014). The level of $\mathrm{P}_{\mathrm{m} \mathrm{LMD}}$ was high compared with $\mathrm{P}_{\mathrm{m} \mathrm{RC}}$ and in the range found with $\mathrm{MIR}_{3 \_ \text {new }}$, and categorization for $\mathrm{Y}_{\mathrm{m} \text { DMI }}$ with 
$\mathrm{RC}$ was only weakly recovered with LMD. The reversal of categories in $\mathrm{P}_{\mathrm{m} \text { LMD }}$ rank before and after feeding was especially puzzling. The LMD operates indirectly and relies on an assumed relationship between breath $\mathrm{CH}_{4}$ concentration and other parameters. As such, it is subject to greater variance and uncertainty compared with quantitative direct measurements. In addition, the accuracy is affected by the proximity of other animals, the distance to the cows' head, the angle of the laser beam, and as shown, the time point in relation to feeding. All of these factors were controlled in the present study, but they may be difficult to control on farm and thus add further uncertainty.

\section{Characteristics of Low-Emitting Cows Identified by $\mathrm{CH}_{4}$ Yield in $\mathrm{RC}$}

Recategorizing cows for low and high emission by the $\mathrm{RC} \mathrm{CH}_{4}$ data was limited to the 28 remaining cows with complete data sets. It can, therefore, be expected that the difference in $\mathrm{CH}_{4}$ yield between the 2 categories in the Brown Swiss population in Switzerland is clearly larger, as that between the $2 \times 10$ cows eventually selected. Still several clear differences between these 2 groups were found. These differences included higher RFI and ECM/BW ratios in low versus high $Y_{m ~ R C}$ cows, whereas differences in feed efficiency were not statistically significant despite similar DMI and different ECM. A low RFI is an indicator for good feed utilization. Hegarty et al. (2007) demonstrated that beef cattle selected for low RFI have a lower $\mathrm{P}_{\mathrm{m}}$ but not a decreased $Y_{m \text { DMI }}$. The RFI itself is also a heritable trait $\left(h^{2}=0.40\right)$, and genetic correlations in the range of 0.18 to 0.84 between RFI and predicted $\mathrm{P}_{\mathrm{m}}$ indicate that selection for lower RFI might also reduce $\mathrm{P}_{\mathrm{m}}$ (de Haas et al., 2011). The indirect effect of differences in feed efficiency of ruminants fed on the same diet explains at least half of the heritability of $\mathrm{Y}_{\mathrm{m} \text { DMI }}$ (Pinares-Patiño et al., 2013). This explanation is independent of the side effect of breeding for ECM yield on $\mathrm{I}_{\mathrm{m} \text { ECM }}(-15 \%$ per $\mathrm{kg}$ of ECM; Knapp et al., 2014). Here, $\mathrm{I}_{\mathrm{m} \text { ECM }}$ is mainly declining because of the lower dilution by maintenance and more concentrate (less fiber) associated with higher ECM yield (Grandl et al., 2016). The lower dilution of maintenance also explains the higher ECM/BW ratio of the low $Y_{m}$ RC cows. In addition, the recategorization also slightly increased ECM difference (on farm: 22 vs. $20 \mathrm{~kg} / \mathrm{d}$ in low and high $\mathrm{P}_{\mathrm{m} \text { MIR }}$ cows; recategorized on station: 23 vs. $19 \mathrm{~kg} / \mathrm{d}$ in low and high $\mathrm{Y}_{\mathrm{m} \mathrm{RC}}$ cows) and thus minimally enhanced the need for allocation of concentrate (10 vs. $7.5 \%$ of diet).

Flay et al. (2019) showed that $Y_{m \text { DMI }}$ was smaller in high RFI animals (consistent with our findings) and hypothesized that this result might be due to a de- creased ruminal NDF digestibility, which is consistent with the present study regarding the RFI. Accordingly, Cabezas-Garcia et al. (2017) found that a reduced $\mathrm{Y}_{\mathrm{m} \text { DMI }}$ was associated with a lower DM and cell wall digestion. The fiber degrading microbes produce less hydrogen, the main substrate for $\mathrm{CH}_{4}$ formation, possibly as a consequence of a faster ruminal digesta passage rate. Indeed, MRT in RR or GIT was suggested to be a main contributor leading to differences in $\mathrm{CH}_{4}$ emissions in ruminants because a shorter MRT leaves less time for $\mathrm{CH}_{4}$ formation from the same amount of feed (Goopy et al., 2014). Goopy et al. (2014) showed that low $Y_{m \text { DMI }}$ sheep have a lower rumen particulate content and a proportionately smaller rumen. However, only part of these findings were recovered in the current study. Indeed the proportion of ruminal acetate was declining at cost of propionate proportion in low compared with high $Y_{m}$ RC cows, a clear sign of a shift in fermentation from fiber toward starch (Hristov et al., 2013). This possibility might have been supported by the concomitant small difference in concentrate allocation. However, total-tract fiber digestibility was not different in the present study. The same is true (with one exception) for RR and GIT MRT of all particle fractions, for which only the smallest particles hade a shorter GIT MRT in the low $Y_{m \text { RC }}$ cows. The estimated gut DM fill was even higher for the low $\mathrm{Y}_{\mathrm{m} \text { RC }}$ cows. The present results therefore point toward a shift in fiber fermentation from the rumen to the hindgut in low compared with high $\mathrm{Y}_{\mathrm{m} \mathrm{RC}}$ cows. In the hindgut, $\mathrm{CH}_{4}$ formation per unit of fiber degraded is lower due to the absence of protozoa and the higher competitiveness of the reductive acetogens (Fievez et al., 1999). In case the category differences measured in the present study were caused by genetics, the genotype indeed appears to have some control over the gut microbial community. Accordingly, transcription of methanogenesis pathway genes was found by Shi et al. (2014) to be lower in low $\mathrm{CH}_{4}$ producing sheep even though methanogen abundance was unaffected. Goopy et al. (2014) also reported that host genetics may influence the rumen ecosystem, which itself might affect ruminal $\mathrm{CH}_{4}$ production.

\section{CONCLUSIONS}

The present study demonstrated that the MIR spectra-based predictions for $\mathrm{CH}_{4}$ production of individual cows on farm could be recovered on a uniform diet could be recovered on farm at the experimental station thus confirming hypothesis 1 . However, the $\mathrm{CH}_{4}$ production of individuals or categorized groups as predicted with MIR did not correspond to that measured in RC, although a slight improvement was noted with the most refined equation (a numerical increase in the 
concordance correlation coefficient to 0.16). This outcome disproves hypothesis 2 and indicates that, at least with forage-based diets and with this range of variation in $\mathrm{CH}_{4}$ values, the proxy is not yet accurate enough to be implemented for selection purposes in Brown Swiss breeding. This assessment also applies to the laser $\mathrm{CH}_{4}$ detector technology. The current study provided detailed information about the characteristics of low $\mathrm{CH}_{4}$ emitting cows in terms of intake, efficiency, and digestion. Compared with high $\mathrm{CH}_{4}$ emitters, low $\mathrm{CH}_{4}$ emitting cows are superior in some variables describing feed and digestive efficiency, which partially confirms hypothesis 3. Still, cows with low $\mathrm{CH}_{4}$ yield will have to be further characterized by mechanistic studies to understand the relative importance of different physiological aspects contributing to the lower $\mathrm{CH}_{4}$ emissions and to clarify the extent to which these aspects are under genetic control.

\section{ACKNOWLEDGMENTS}

We are grateful to the MIR experts (F. Dehareng and N. Gengler) from CRA-W and Gembloux AgroBio Tech, Belgium, for providing refined equations and assisting in applying them in practical conditions. We thank the staff of AgroVet-Strickhof and ETH Zurich for their assistance, especially S. Amelchanka, P. Bucher, M. Hunziker, C. Kunz, E. Manzocchi, M. Mergani, R. Müller, T. Stiefel, R. Stoz, and M. Terranova. Moreover, we are grateful to the farmers for letting their cows participate and to Braunvieh Schweiz for the collaboration. The study was supported by the European Cooperation in Science and Technology (COST Action FA 1302, "MethaGene"), the Swiss State Secretariat for Education, Research and Innovation, and Qualitas AG. The authors have not stated any conflicts of interest.

\section{REFERENCES}

Agroscope. 2019. Feeding Recommendations and Nutrient Tables for Ruminants (in German). Accessed Dec. 5, 2019. www.agroscope .admin.ch/agroscope/de/home/services/dienste/futtermittel/ fuetterungsempfehlungen-wiederkaeuer.html.

Alemu, A. W., D. Vyas, G. Manafiazar, J. A. Basarab, and K. A. Beauchemin. 2017. Enteric methane emissions from low- and highresidual feed intake beef heifers measured using GreenFeed and respiration chamber techniques. J. Anim. Sci. 95:3727-3737. https: //doi.org/10.2527/jas.2017.1501.

AOAC International. 1995. Official Methods of Analysis. AOAC International, Arlington, VA.

Bell, M. J., J. Craigon, N. Saunders, J. R. Goodman, and P. C. Garnsworthy. 2018. Does the diurnal pattern of enteric methane emissions from dairy cows change over time? Animal 12:2065-2070. https://doi.org/10.1017/S1751731118000228.

Cabezas-Garcia, E. H., S. J. Krizsan, K. J. Shingfield, and P. Huhtanen. 2017. Between-cow variation in digestion and rumen fermentation variables associated with methane production. J. Dairy Sci. 100:4409-4424. https://doi.org/10.3168/jds.2016-12206.
Chagunda, M. G., D. Ross, J. Rooke, T. Yan, J.-L. Douglas, L. Poret, N. R. McEwan, P. Teeranavattanakul, and D. J. Roberts. 2013. Measurement of enteric methane from ruminants using a handheld laser methane detector. Acta Agric. Scand. A Anim. Sci. 63:68-75. https://doi.org/10.1080/09064702.2013.797487.

Chagunda, M. G. G. 2013. Opportunities and challenges in the use of the Laser Methane Detector to monitor enteric methane emissions from ruminants. Animal 7(Suppl. 2):394-400. https://doi.org/10 $.1017 /$ S1751731113000724.

de Haas, Y., M. Pszczola, H. Soyeurt, E. Wall, and J. Lassen. 2017. Phenotypes to genetically reduce greenhouse gas emissions in dairying. J. Dairy Sci. 100:855-870. https://doi.org/10.3168/jds .2016-11246.

de Haas, Y., J. J. Windig, M. P. L. Calus, J. Dijkstra, M. de Haan, A. Bannink, and R. F. Veerkamp. 2011. Genetic parameters for predicted methane production and potential for reducing enteric emissions through genomic selection. J. Dairy Sci. 94:6122-6134. https://doi.org/10.3168/jds.2011-4439.

Denninger, T. M., F. Dohme-Meier, L. Eggerschwiler, A. Vanlierde, F. Grandl, B. Gredler, M. Kreuzer, A. Schwarm, and A. Münger. 2019. Persistence of differences between dairy cows categorized as low or high methane emitters, as estimated from milk mid-infrared spectra and measured by GreenFeed. J. Dairy Sci. 102:1175111765. https://doi.org/10.3168/jds.2019-16804.

Fievez, V., F. Piattoni, L. Mbanzamihigo, and D. Demeyer. 1999. Reductive acetogenesis in the hindgut and attempts to its induction in the rumen. J. Appl. Anim. Res. 16:1-22. https://doi.org/10 $.1080 / 09712119.1999 .9706258$.

Flay, H. E., B. Kuhn-Sherlock, K. A. Macdonald, M. Camara, N. Lopez-Villalobos, D. J. Donaghy, and J. R. Roche. 2019. Selecting cattle for low residual feed intake did not affect daily methane production but increased methane yield. J. Dairy Sci. 102:2708-2713. https://doi.org/10.3168/jds.2018-15234.

Garnsworthy, P. C., J. Craigon, J. H. Hernandez-Medrano, and N. Saunders. 2012a. On-farm methane measurements during milking correlate with total methane production by individual dairy cows. J. Dairy Sci. 95:3166-3180. https://doi.org/10.3168/jds.2011-4605.

Garnsworthy, P. C., J. Craigon, J. H. Hernandez-Medrano, and N. Saunders. 2012b. Variation among individual dairy cows in methane measurements made on farm during milking. J. Dairy Sci. 95:3181-3189. https://doi.org/10.3168/jds.2011-4606.

Goopy, J. P., A. Donaldson, R. Hegarty, P. E. Vercoe, F. Haynes, M. Barnett, and V. H. Oddy. 2014. Low-methane yield sheep have smaller rumens and shorter rumen retention time. Br. J. Nutr. 111:578-585. https://doi.org/10.1017/S0007114513002936.

Grandl, F., S. L. Amelchanka, M. Furger, M. Clauss, J. O. Zeitz, M. Kreuzer, and A. Schwarm. 2016. Biological implications of longevity in dairy cows: 2. Changes in methane emissions and efficiency with age. J. Dairy Sci. 99:3472-3485. https://doi.org/10.3168/jds .2015-10262.

Grandl, F., A. Schwarm, S. Ortmann, M. Furger, M. Kreuzer, and M. Clauss. 2018. Kinetics of solutes and particles of different size in the digestive tract of cattle of $0.5-10$ yr of age, and relationships with methane production. J. Anim. Physiol. Anim. Nutr. (Berl.) 102:639-651. https://doi.org/10.1111/jpn.12862.

Grelet, C., J. A. Fernández Pierna, P. Dardenne, H. Soyeurt, A. Vanlierde, F. Colinet, C. Bastin, N. Gengler, V. Baeten, and F. Dehareng. 2017. Standardization of milk mid-infrared spectrometers for the transfer and use of multiple models. J. Dairy Sci. 100:79107921. https://doi.org/10.3168/jds.2017-12720.

Grovum, W. L., and V. J. Williams. 1973. Rate of passage of digesta in sheep. 4. Passage of marker through the alimentary tract and the biological relevance of rate-constants derived from the changes in concentration of marker in faeces. Br. J. Nutr. 30:313-329. https:/ /doi.org/10.1079/bjn19730036.

Gruber, L., F. J. Schwarz, D. Erdin, B. Fischer, H. Spiekers, H. Steingaß, U. Meyer, A. Chassot, T. Jilg, A. Obermaier, and T. Guggenberger. 2004. Prediction of Feed Intake of Dairy Cows. Pages 484-504 in Database of 10 Research and University Institutes of Germany, Austria and Switzerland (in German). VDLUFA-Schrift- 
enreihe 60, VDLUFA-Verlag, Darmstadt, Germany. Accessed June 12, 2019.www.vdlufa.de/download/Kongressband_2004.pdf.

Hegarty, R. S., J. P. Goopy, R. M. Herd, and B. McCorkell. 2007. Cattle selected for lower residual feed intake have reduced daily methane production. J. Anim. Sci. 85:1479-1486. https://doi.org/ $10.2527 /$ jas. 2006-236.

Hristov, A. N., J. Oh, J. L. Firkins, J. Dijkstra, E. Kebreab, G. Waghorn, H. P. S. Makkar, A. T. Adesogan, W. Yang, C. Lee, P. J. Gerber, B. Henderson, and J. M. Tricarico. 2013. Mitigation of methane and nitrous oxide emissions from animal operations: I. A review of enteric methane mitigation options. J. Anim. Sci. 91:5045-5069. https://doi.org/10.2527/jas.2013-6583.

Huhtanen, P., and U. Kukkonen. 1995. Comparison of methods, markers, sampling sites and models for estimating digesta passage kinetics in cattle fed at two levels of intake. Anim. Feed Sci. Technol. 52:141-158. https://doi.org/10.1016/0377-8401(94)00699-A.

IPCC (Intergovernmental Panel on Climate Change). 2006. Emissions from livestock and manure management. Pages 10.1-10.87 in Guidelines for National Greenhouse Inventories. Vol. 4. Agriculture, Forestry and Other Land Use. Accessed November 14, 2019. www.ipcc-nggip.iges.or.jp/public/2006gl/pdf/4_Volume4/V4_10 _Ch10_Livestock.pdf.

Jonker, A., S. Hickey, C. Pinares-Patiño, J. McEwan, S. Olinga, A. Díaz, G. Molano, S. MacLean, E. Sandoval, R. Harland, D. Birch, B. Bryson, K. Knowler, and S. Rowe. 2017. Sheep from low-methane-yield selection lines created on alfalfa pellets also have lower methane yield under pastoral farming conditions. J. Anim. Sci. 95:3905-3913. https://doi.org/10.2527/jas2017.1709.

Knapp, J. R., G. L. Laur, P. A. Vadas, W. P. Weiss, and J. M. Tricarico. 2014. Enteric methane in dairy cattle production: Quantifying the opportunities and impact of reducing emissions. J. Dairy Sci. 97:3231-3261. https://doi.org/10.3168/jds.2013-7234.

Lassen, J., and P. Løvendahl. 2016. Heritability estimates for enteric methane emissions from Holstein cattle measured using noninvasive methods. J. Dairy Sci. 99:1959-1967. https://doi.org/10 $.3168 /$ jds.2015-10012.

Münger, A., and M. Kreuzer. 2008. Absence of persistent methane emission differences in three breeds of dairy cows. Aust. J. Exp. Agric. 48:77-82. https://doi.org/10.1071/EA07219.

Munn, A., M. Stewart, E. Price, A. Peilon, T. Savage, I. Van Ekris, and M. Clauss. 2015. Comparison of gut fill in sheep (Ovis aries) measured by intake, digestibility, and digesta retention compared with measurements at harvest. Can. J. Zool. 93:747-753. https:// doi.org/10.1139/cjz-2014-0314.

Niu, M., E. Kebreab, A. N. Hristov, J. Oh, C. Arndt, A. Bannink, A. R. Bayat, A. F. Brito, T. Boland, D. Casper, L. A. Crompton, J. Dijkstra, M. A. Eugène, P. C. Garnsworthy, N. Haque, A. L. F. Hellwing, P. Huhtanen, M. Kreuzer, B. Kuhla, P. Lund, J. Madsen, C. Martin, S. C. McClelland, M. McGee, P. Moate, S. Muetzel, O. Muñoz, P. O'Kiely, N. Peiren, C. K. Reynolds, A. Schwarm, K. J. Shingfield, T. M. Storlien, M. R. Weisbjerg, D. R. Yañez-Ruiz, and Z. Yu. 2018. Prediction of enteric methane production, yield and intensity in dairy cattle using an intercontinental database. Glob. Chang. Biol. 24:3368-3389. https://doi.org/10.1111/gcb.14094.

Pinares-Patiño, C. S., S. M. Hickey, E. A. Young, K. G. Dodds, S. MacLean, G. Molano, E. Sandoval, H. Kjestrup, R. Harland, C. Hunt, N. K. Pickering, and J. C. Mc Ewan. 2013. Heritability estimates of methane emissions from sheep. Animal 7(Suppl 2):316-321. https://doi.org/10.1017/S1751731113000864.

Pinares-Patiño, C. S., J. McEwan, K. G. Dodds, E. A. Cárdenas, R. S. Hegarty, J. P. Koolaard, and H. Clark. 2011. Repeatability of methane emissions from sheep. Anim. Feed Sci. Technol. 166167:210-218. https://doi.org/10.1016/j.anifeedsci.2011.04.068.

Pinheiro, J., D. Bates, S. DebRoy, D. Sarkar, and R Core Team. 2017. nlme: Linear and nonlinear mixed effects models. https://CRAN .R-project.org $/$ package $=$ nlme.

R Core Team. 2018. R: A language and environment for statistical computing. R Foundation for Statistical Computing, Vienna, Austria. https://www.R-project.org.
Ricci, P., M. G. G. Chagunda, J. Rooke, J. G. M. Houdijk, C.-A. Duthie, J. Hyslop, R. Roehe, and A. Waterhouse. 2014. Evaluation of the laser methane detector to estimate methane emissions from ewes and steers. J. Anim. Sci. 92:5239-5250. https://doi.org/10 $.2527 /$ jas.2014-7676

Rombach, M., A. Münger, J. Niederhauser, K.-H. Südekum, and F. Schori. 2018. Evaluation and validation of an automatic jaw movement recorder (RumiWatch) for ingestive and rumination behaviors of dairy cows during grazing and supplementation. J. Dairy Sci. 101:2463-2475. https://doi.org/10.3168/jds.2016-12305.

Shetty, N., G. Difford, J. Lassen, P. Løvendahl, and A. J. Buitenhuis. 2017. Predicting methane emissions of lactating Danish Holstein cows using Fourier transform mid-infrared spectroscopy of milk. J. Dairy Sci. 100:9052-9060. https://doi.org/10.3168/jds.2017-13014.

Shi, W., C. D. Moon, S. C. Leahy, D. Kang, J. Froula, S. Kittelmann, C. Fan, S. Deutsch, D. Gagic, H. Seedorf, W. J. Kelly, R. Atua, C. Sang, P. Soni, D. Li, C. S. Pinares-Patiño, J. C. McEwan, P. H. Janssen, F. Chen, A. Visel, Z. Wang, G. T. Attwood, and M. Rubin. 2014. Methane yield phenotypes linked to differential gene expression in the sheep rumen microbiome. Genome Res. 24:15171525. https://doi.org/10.1101/gr.168245.113.

Sorg, D., G. F. Difford, S. Mühlbach, B. Kuhla, H. H. Swalve, J. Lassen, T. Strabel, and M. Pszczola. 2018. Comparison of a laser methane detector with the GreenFeed and two breath analysers for on-farm measurements of methane emissions from dairy cows. Comput. Electron. Agric. 153:285-294. https://doi.org/10.1016/j .compag.2018.08.024.

Sorg, D., S. Mühlbach, F. Rosner, B. Kuhla, M. Derno, S. Meese, A. Schwarm, M. Kreuzer, and H. Swalve. 2017. The agreement between two next-generation laser methane detectors and respiration chamber facilities in recording methane concentrations in the spent air produced by dairy cows. Comput. Electron. Agric. 143:262-272. https://doi.org/10.1016/j.compag.2017.10.024.

Steinfeld, H., P. Gerber, T. D. Wassenaar, V. Castel, M. Rosales, and C. De Haan. 2006. Livestock's long shadow. FAO, Rome, Italy.

Thielemans, M.-F., E. Francois, C. Bodart, A. Thewis, F. Dupont, L. Lallemand, and C. Malburny. 1978. Mesure du transit gastrointestinal chez le porc a l'aide des radiolanthanides. Comparaison avec le mouton. Ann. Biol. Anim. Biochim. Biophys. 18(2A):237-247. https://doi.org/10.1051/rnd:19780203.

Udén, P., P. E. Colucci, and P. J. Van Soest. 1980. Investigation of chromium, cerium and cobalt as markers in digesta. Rate of passage studies. J. Sci. Food Agric. 31:625-632. https://doi.org/10 $.1002 /$ jsfa.2740310702

van Gastelen, S., and J. Dijkstra. 2016. Prediction of methane emission from lactating dairy cows using milk fatty acids and midinfrared spectroscopy. J. Sci. Food Agric. 96:3963-3968. https:// doi.org/10.1002/jsfa.7718.

Vanlierde, A., H. Soyeurt, N. Gengler, F. G. Colinet, E. Froidmont, M. Kreuzer, F. Grandl, M. Bell, P. Lund, D. W. Olijhoek, M. Eugène, C. Martin, B. Kuhla, and F. Dehareng. 2018. Development of an equation for estimating methane emissions of dairy cows from milk Fourier transform mid-infrared spectra by using reference data obtained exclusively from respiration chambers. J. Dairy Sci. 101:7618-7624. https://doi.org/10.3168/jds.2018-14472.

Vanlierde, A., M.-L. Vanrobays, F. Dehareng, E. Froidmont, H. Soyeurt, S. McParland, E. Lewis, M. H. Deighton, F. Grandl, M. Kreuzer, B. Gredler, P. Dardenne, and N. Gengler. 2015. Innovative lactation-stage-dependent prediction of methane emissions from milk mid-infrared spectra. J. Dairy Sci. 98:5740-5747. https: //doi.org/10.3168/jds.2014-8436.

Vanlierde, A., M.-L. Vanrobays, N. Gengler, P. Dardenne, E. Froidmont, H. Soyeurt, S. McParland, E. Lewis, M. H. Deighton, M. Mathot, and F. Dehareng. 2016. Milk mid-infrared spectra enable prediction of lactation-stage-dependent methane emissions of dairy cattle within routine population-scale milk recording schemes. Anim. Prod. Sci. 56:258-264. https://doi.org/10.1071/AN15590. 